\title{
GESLA Version 3: A major update to the global higher-frequency sea-level dataset
}

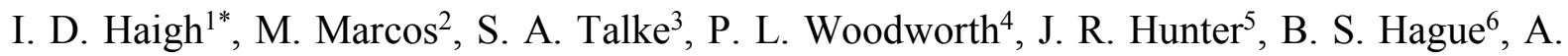 \\ Arns $^{7}$, E. Bradshaw ${ }^{8}$, P. Thompson ${ }^{9}$ \\ 1. School of Ocean and Earth Science, University of Southampton, National Oceanography Centre, \\ European Way, Southampton, SO14 3ZH, UK \\ 2. IMEDEA (UIB-CSIC), 07190 Esporles, Balearic Islands, Spain \\ 3. Department of Civil and Environmental Engineering, California Polytechnic State University, San Luis \\ Obispo, California, USA \\ 4. National Oceanography Centre, Liverpool L3 5DA, UK \\ 5. Institute for Marine and Antarctic Studies, University of Tasmania, Hobart, Tasmania, Australia \\ 6. Australian Bureau of Meteorology, GPO Box 1289, Melbourne, Victoria, Australia \\ 7. Faculty of Agricultural and Environmental Sciences, University of Rostock, Justus-von-Liebig-Weg 6, \\ 18059, Rostock, Germany \\ 8. British Oceanographic Data Centre, National Oceanography Centre, Liverpool L3 5DA, UK \\ 9. Department of Oceanography, University of Hawai 'i at Mānoa, Honolulu, Hawai ' $i$, USA \\ * School of Ocean and Earth Science, University of Southampton, National Oceanography Centre, \\ European Way, Southampton, SO14 3ZH,UK; I.D.Haigh@soton.ac.uk
}

\begin{abstract}
This paper describes a major update to the quasi-global, higher-frequency sea-level dataset known as GESLA (Global Extreme Sea Level Analysis). Versions 1 (released 2009) and 2 (released 2016) of the dataset have been used in many published studies, across a wide range of oceanographic and coastal engineering-related investigations concerned with evaluating tides, storm surges, extreme sea levels and other related processes. The third version of the dataset (released 2021), presented here, contains twice the number of years of data $(91,021)$, and nearly four times the number of records $(5,119)$, compared to version 2 . The dataset consists of records obtained from multiple sources around the world. This paper describes the assembly of the dataset, its processing and its format, and outlines potential future improvements. The dataset is available from https://www.gesla.org.
\end{abstract}




\section{*** Please note that this is an EarthArXiv preprint and not peer-reviewed. This work is provided by the authors as a means to ensure timely dissemination of scholarly work on a non-commercial basis. $* * *$}

\section{INTRODUCTION}

Having access to high-quality sea-level measurements worldwide is vital for many oceanographic and coastal applications. For example, sea-level records form the basis of our understanding of changes in mean sea level, which affects the livelihoods of hundreds of millions of people living in the world's coastal regions and is one of the key indicators of climate change (Oppenheimer et al., 2019). Coastal sea-level extremes are among the costliest and potentially most hazardous impacts affecting densely populated coastal regions (Wong et al. 2014). Analyses of sea-level records help engineers and coastal managers define flood defence heights and other coastal protection measures. Measurements of sea level are used to map the timing and heights of astronomical tides and calibrate and validate both operational and scientific numerical models of oceanic processes (Muis et al., 2020). Furthermore, coastal sea-level measurements form a key component of the datums used in nautical charts and geodetic surveys, and influence legal definitions of shoreline boundaries (Shalowitiz, 1962). Building on an earlier study (Woodworth et al., 2017), this paper is concerned with extending a global dataset of higher-frequency (at least hourly) sea-level records from tide gauges at as many locations as possible worldwide.

The international body responsible for coordinating collection and access to in situ sealevel records is the Global Sea Level Observing System (GLOSS), which was established by the UNESCO Intergovernmental Oceanographic Commission (IOC) in 1985 to support a broad research and operational user base. Multiple GLOSS data centers contribute to the aggregation of global sea-level datasets with varying temporal resolutions and levels of quality control. Global datasets of monthly and annual mean sea level have been available for many decades via the Permanent Service for Mean Sea Level (PSMSL). Established in 1933, PSMSL has been responsible for the collection of mean sea-level data from global tide gauges (Holgate et al., 2013) and has been used, with altimeter records, in most past mean sea-level trend and variability studies. PSMSL has always had good coverage globally because, historically, tide gauge operators have been more willing to share monthly mean data, rather than higherfrequency data. However, higher-frequency data is required for the study of ocean tides, storm surges and extreme sea levels (Woodworth et al., 2019). The GLOSS dataset for researchquality hourly sea-level data is the Joint Archive for Sea Level (Caldwell et al., 2015), which was established in 1987 and is hosted by the University of Hawaii Sea Level Center (UHSLC). This dataset is composed of nearly 18,000 years of hourly sea-level data from 696 records in 


\section{***Please note that this is an EarthArXiv preprint and not peer-reviewed. This work is provided by the authors as a means to ensure timely dissemination of scholarly work on a non-commercial basis.***}

97 countries. These data have been inspected for outliers, timing issues, and datum shifts, and efforts have been made to reconcile quality issues with the data originators. The locations of records in the UHSLC dataset are distributed globally, with care given to balance global coverage with the time-intensive process of quality assessment. Thus, the UHSLC dataset excludes many records in densely sampled regions in order to provide global coverage while maintaining an update cycle of approximately two years.

The GESLA (Global Extreme Sea Level Analysis) project was established, over a decade ago, to increase access to a greater volume of the global hourly and even higher-frequency sealevel data, than is available in the UHSLC dataset. The original aim of the project was to assemble as many higher-frequency sea-level records as were readily available into a common format with consistent quality control flags, to make it easier for researchers to maximize the geographic density of data, capturing extreme sea levels on a global scale. The first GESLA dataset, denoted GESLA-1, was assembled in 2009 and contained 21,197 years of higherfrequency measurements from 675 records. The majority of the data were obtained by ingesting UHSLC and other GLOSS data. The GLOSS datasets were then supplemented by a small number of other records obtained from national data centres or from contributions received from colleagues in the sea-level community. GESLA-1 was first used in a study of sea-level extremes by Menéndez and Woodworth (2010). Subsequent publications based on GESLA-1 included, for example, Hunter et al. (2013); Mawdsley et al., (2015) and Marcos et al. (2015), and GESLA-1 was used in the Intergovernmental Panel on Climate Change's (IPCC) Fifth Assessment Report (Rhein et al., 2013; Church et al., 2013; Wong et al., 2014).

After some years, it became apparent that GESLA-1 needed updating to include additional data and to extend its coverage in under-represented areas. Thus GESLA-2 was assembled in 2015 and 2016. The compilation of GESLA-2 is described in detail in Woodworth et al. (2017). This second version contained almost twice the amount of data compared to the first. GESLA-2 contained 39,151 years of higher-frequency measurements of sea level from 1,355 records; again, the UHSLC dataset made up a significant proportion of this database. Since its release in early 2016, GESLA-2 has been used in a wide range of ocean research, examples including:

1. Assessment of temporal and spatial changes in extreme sea levels and links to regional climate (e.g., Marcos and Woodworth, 2017; Rashid et al., 2021); 
***Please note that this is an EarthArXiv preprint and not peer-reviewed. This work is provided by the authors as a means to ensure timely dissemination of scholarly work on a non-commercial basis.***

2. Calculation of extreme sea-level return periods and sea-level allowances (e.g., Wahl et al., 2017; Tsitsikas, 2018; Woodworth et al., 2021);

3. Provision of information for flood inundation studies (e.g., Hunter et al., 2017);

4. Analysis of non-linear interactions between tides and non-tidal residuals or skew surges

(e.g., Santamaria-Aguilar and Vafeidis, 2019; Arns et al., 2020);

5. Investigations of changes in ocean tidal constituents and levels (e.g., Schindelegger et al., 2018; Ray, 2020);

6. Examinations of the magnitude and changes in the perigean and nodal inter annual tidal cycles (e.g., Woodworth and Hibbert, 2018; Peng et al., 2019);

7. Validation of regional and global ocean tide and tide/surge hydrodynamic models (e.g., Piccioni et al., 2018; Muis et al., 2020);

8. Assessment of compound flooding from coastal, fluvial and pluvial sources (e.g., Ward et al., 2018); and

9. Other applications (e.g., Wolff et al., 2018; Tadesse et al., 2020).

GESLA-2 data has also been used in the IPCC Special Report on Ocean and the Cryosphere (Oppenheimer et al., 2019), and in the Sixth Assessment Report (Fox-Kemper et al., 2021). Furthermore, a secondary database of tidal constituents has been derived from GESLA-2 by Piccioni et al. (2019) and another for skew surges has also been made available through the GESLA website, after Marcos and Woodworth (2017). All the studies that the authors are aware of that have used the GESLA dataset to date are listed on https://www.gesla.org. In 2016, GESLA was made an official GLOSS dataset.

In this paper we describe the development of Version 3 of the dataset, which provides a major update. Section 2 of this paper describes the data sources, the data processing and the revised GESLA data format. Access to the data set is described in Section 3. A discussion and conclusions are given in Section 4.

\section{DATA DESCRIPTION AND DEVELOPMENT}

Here we describe the data sources, record locations and number of years of data (Section 2.1), we outline the data processing and format (Section 2.2), we describe the usage licenses (Section 2.3) and we discuss the dataset in regards to the recently established FAIR (findable, accessible, interoperable and reusable) data principles (Section 2.4). 
***Please note that this is an EarthArXiv preprint and not peer-reviewed. This work is provided by the authors as a means to ensure timely dissemination of scholarly work on a non-commercial basis. $* * *$

\subsection{Data Sources}

135 We obtained the higher-frequency sea-level dataset for GESLA-3 from 36 international and national data providers (Table 1). Providers are ordered by the number of years of sea-level data available (see Table 2). Below, we use the abbreviated names of the providers; readers should refer to Table 1 for their full names. We define the length of a sea-level dataset for a particular record, as being the number of years available; a year is a calendar year containing one or more sea-level measurement for that particular record. We use the term record to refer to a sea-level dataset at a particular tide gauge. A specific tide gauge station can have more than one record; either because: (1) a duplicate record for that station is available from different providers; or (2) because sometimes sea-level time series for the same station are split into different records when there are datum jumps or changes in the location or instrument (i.e., the UHSLC dataset contains such records, and these are donated by letters, A, B, C, etc. after the station code).

Data were obtained and processed as follows. First, full records were downloaded again from all the sources used to compile GESLA-2 (Table 2 in Woodworth et al., 2017), except where noted below. Therefore, any changes to quality control or datums made since 2015/16 are reflected in GESLA-3. GESLA-2 included 191 records from the GLOSS Delayed Model dataset (source 1 glossdm-bodc, see Table 2 in Woodworth et al., 2017). However, this dataset has not been updated for many years and data from all but two of these records (Aasiaat and Maniitsoq in Greenland) are now available from other sources (see Table 1). Hence, we only included these two records in GESLA-3. GESLA-2 also included two datasets for Australia (source 28 johnhunter and 29 national_tidal_centre, see Table 2 in Woodworth et al., 2017). We did not include either of these in GESLA-3; instead, we replaced them with a more up-todate sea-level dataset complied by BOM, with a greater number of records. Next, we obtained measurements from 16 additional providers that were not in GESLA-2 (indicated by the grey shading in Table 1). GESLA-3 now includes higher-frequency sea-level data obtained from paper records via data archaeology (DA) exercises. These included 21 records in the USA collated by Bromirski et al., 2003, Talke et al. (2014, 2018, 2020, 2021), Familkhalili \& Talke (2016), Chant et al. (2018), and Ray and Talke (2019), 5 records in the UK by Haigh et al. (2009) and 3 records in Spain digitised by Marcos et al. (2013, 2021). These datasets include 


\section{*** Please note that this is an EarthArXiv preprint and not peer-reviewed. This work is provided by the authors as a means to ensure timely dissemination of scholarly work on a non-commercial basis. $* * *$}

165 Francisco, 1858-1877) and stations on the US East Coast and Europe from the late $19^{\text {th }}$ century.

While some information such as the datum and time zone are available in GESLA-3 metadata for these DA sources, users are referred to the references above for more detailed discussions of data provenance and quality.

For five of the 36 sources within GESLA-3 (i.e., UHSLC, NOAA, NHS, MI-C and MI-R), we downloaded the data automatically and rapidly via an API (Application Programming Interface). For the NHS dataset, we combined the more recent data since the late 1980's, download via API, with historical data going back as far as 1915, that were provided to us directly. For 25 of the 36 sources, we manually downloaded the data from provider websites. For some providers, the data could be downloaded in bulk. However, for other providers the data had to be downloaded one record at a time. Furthermore, for a few providers, the data had to be downloaded in 1 to 15 -year blocks, for each record. For the remaining six sources (i.e., DA, DMI, NOC, ESEAS, ICG and UZ), we obtained the data directly from the provider or copied the data from GESLA-2 (when updates were not available). The US providers USGS, CDWR, SFWMD, NWFWMD and NCDEM, and the Dutch provider RWS, did not discern between tidally influenced gauges and river-only gauges; in these cases, we hand-selected stations where there was the obvious presence of tidal forcing during at least part of the year and we did not include the river-only records. The NOAA and MEDS datasets included records in the Great Lakes, and we retained these in GESLA-3.

In GESLA-1 and GESLA-2, we focused primarily on obtaining long records. However, many shorter records (a few days to a few years) are now being routinely provided by data centres. Furthermore, as described in Section 1, the GESLA dataset is increasingly being used for a wider range of analysis purposes. Short records, even those up to a month in duration, have proved useful for a variety of applications, including the calculation of harmonic constituents and the validation of numerical models. Therefore, for GESLA-3, we included all the higher-frequency records that were available from the 36 providers, as long as they had at least 30 days of measurements. As discussed below, inclusion of short records is a primary reason why the number of records and years greatly increased in GESLA-3, compared to GESLA-2.

For most sources we obtained the so called 'delayed mode' or 'research quality' data, which typically becomes available to a user with a delay from days to years, enabling the data centres to perform quality control and include flags to highlight periods of good, suspect and bad data 


\section{*** Please note that this is an EarthArXiv preprint and not peer-reviewed. This work is provided by the authors as a means to ensure timely dissemination of scholarly work on a non-commercial basis. $* * *$}

values. The latest years available for each source are listed in Table 2. For around half of the sources, we obtained data up to October 2021 (the dates we did the final processing of the dataset). Most other datasets included data until the end of 2019 or 2020.

The number of records and years of data in GESLA-3 are listed in Table 2 for each of the 36 contributing sources. In total, GESLA-3 contains 91,021 years from 5,119 records. A map showing the locations of the records for GESLA-3 is shown in Figure 1. The areas where the coverage has most improved, compared to GESLA-2, are North America (Figure 2a), Europe (Figure 2b), Japan (Figure 2c) and Australia (Figure 2d). This is illustrated clearly in Figure 3, which shows the location of new records in GESLA-3 that are more than $50 \mathrm{~km}$ from a record in GESLA-2. Coverage outside of these regions is primarily achieved by ingesting the UHSLC dataset, which continues to be updated with new data, but has remained consistent in terms of the number and location of included stations. Coverage in North America has increased enormously for several reasons. First, we added all datasets available from NOAA and MEDS, not just the longer datasets. Furthermore, we also incorporated new datasets from the USGS, CDWR, SFWMD, NWFWMD, NCDEM and UNAM. In Europe, the largest increase in coverage stems from the records added from CMEMS. However, note many of the records from CMEMS only cover more recent decades, and not the full period often available from other providers (e.g., for Newlyn, data is available from 1915 from BODC, but only from 1990 from CMEMS). We also added new datasets for the UK from the CCO, for Ireland from MI$\mathrm{R}$ and MI-C, and for Germany from WSV. Coverage has increased significantly in Japan, from 80 records in GELSA-2 to 207 in GESLA-3. GESLA-2 only included data from the JODC_JMA. In GESLA-3 we have added data from the JODC_JCG, JODC_GIAJ and JODC_PAHB. For Australia, the number of records has increased from 47 to 125, resulting from the development of the Australian National Collection of Homogenised Observations of Relative Sea Level (ANCHORS, Hague et al., 2021). The ANCHORS methodology applied statistical techniques to remove stepwise changes in annual means resulting, for example, from datum shifts and tide gauge relocations, for long tide-gauge records. So that quality control processes applied in GESLA-3 are internally consistent, we only included unhomogenised data from ANCHORS records, which is then quality controlled as described in Section 2.2. In the process of developing ANCHORS, many additional shorter records suitable for GESLA-3 were identified and are also included here. 


\section{*** Please note that this is an EarthArXiv preprint and not peer-reviewed. This work is provided by the authors as a means to ensure timely dissemination of scholarly work on a non-commercial basis. $* * *$}

In GESLA-3, records are available for 114 countries. The countries with the highest number of records are the USA and Canada, reflecting in part the vast length of the coastlines in these countries. The number of countries, covered by each of the 36 contributing sources is listed in Table 2 (final column). The UHSLC dataset contains records from 97 countries, significantly higher than any of the other sources. This illustrates how essential the UHSLC dataset is for achieving good global coverage in GESLA-3 (and earlier versions).

GESLA-3 contains 91,021 years of sea-level data (Table 2). The number of records containing different numbers of years are shown in Figures 4a. The record, with the most years of data (168 years between 1851 and 2021) is Olands Norra Udde from the SMHI, and the next longest record is Brest (165 years between 1846 and 2021) from REFMAR. The number of records with different ranges of years, is shown in Figure 4b. The inclusion of many new short (i.e., $<5$ years) records is evident, but GESLA-3 also includes many new longer records, for example, for Japan from JODC_JCG, JODC_GIAJ and JODC_PAHB, and for the USA and Europe from the DA sources. The record locations, with corresponding numbers of years, are shown in Figure 5. The majority of the sites with $>100$ years are located in North America and Europe. Four further sites are located in Panama and Australia. The number of records starting in particular year ranges is shown in Figure 4c. The location of records starting in the corresponding year ranges are shown in Figure 6. The earliest record, Katwijk in the Netherlands, starts in the year 1805 (but this record only contains 3 years). Hence, GESLA-3 spans the 217-year period from 1805 to 2021. The next earliest record, Saint Nazaire in France starts in the year 1821 (this record contains 134 years of data). The number of records containing data each year between 1805 and 2021, is shown in Figure 6d, for GESLA-3, plotted alongside the same information for the earlier GESLA-1 and GESLA-2 datasets.

\subsection{Data Processing and Format}

253 The sea-level dataset we obtained from the 36 providers have differing units, time zones and formats, and quality control flags are variously defined. As with GESLA-1 and GESLA-2, we converted height units to metres, the time zone of each record was adjusted to Coordinated Universal Time (UTC), we matched the specific data provider quality control flags to our defined GESLA flags (see below), and we processed the records into a standard format (a 


\section{*** Please note that this is an EarthArXiv preprint and not peer-reviewed. This work is provided by the authors as a means to ensure timely dissemination of scholarly work on a non-commercial basis. $* * *$}

259 Daylight Savings time in summer and we first shifted these to standard time, before converting to UTC; however, since the times of annual shifts between Daylight Savings Time and Standard Time are imperfectly documented, some errors may remain.

In most instances, we did not adjust the frequency of the records, which in all cases was at least hourly, although several sources have data at higher-frequency $(6,10$ or 15 minutes). When given an option (for example on a provider's website), we always downloaded the hourly data, over higher-frequency data, as hourly data is adequate for most analyses that have previously been undertaken using GESLA, and it reduces the file sizes of the final processed datasets. Within the CMEMS dataset, the French data is provided at different frequencies for the same tide gauge. For example, the dataset at Brest is provided at 1-, 2-, 5-, 10- and 60minute frequencies (for different overlapping periods). The higher-frequency records are generally much shorter, and the quality control is often less rigorous, and so we ignored these and only included, in most instances, the hourly resolution dataset. The WSV data had a resolution of 1-minute and the USGS, CDWR, SWFWMD, NWFWMD and NCDEM data had resolutions between 1 and 15 minutes. We averaged these records, to hourly values, again to reduce the file size of the processed dataset. To do this, we selected all the data that lay within plus or minus 30 minutes from a specific hour, and averaged these values. Data from some providers is temporally regular (e.g., there is a date/time stamp every single hour) while for other providers the data is irregular (e.g., there is not a date/time stamp every hour - some are missing). In some cases, the frequency changes over time (e.g., the first part of the record is hourly, while the more recent period has a frequency of 15-minutes). We did not attempt to make the dataset temporally regular, or (with the exception of that mentioned above) adjust the frequency, as most analysis approaches can handle data with irregular time scales. Furthermore, we wanted the records to remain as consistent as possible with that provided by the originating agency.

For consistency, we have kept the format of the GESLA-3 data files virtually the same as in GESLA-2. As illustrated in Table 3, each text file contains 41 lines of header information, followed by the data itself. In GESLA-2, we listed only the name of the contributor of the data. However, in GESLA-3 we have included two extra header lines recording the website and the contact details of the contributor. For the international data centres, such as the UHSLC and CMEMS, the data they provide originate from different national centres. To ensure the originators of the data receive the credit they deserve, and so that the data can be traced back 


\section{***Please note that this is an EarthArXiv preprint and not peer-reviewed. This work is provided by the authors as a means to ensure timely dissemination of scholarly work on a non-commercial basis. $* * *$}

291

to the original providers, we have included three extra header lines listing the originator of the data, their website and contact details. Where the contributor and originator are the same, the information is simply repeated. In GESLA-3 we have also added a new header line to indicate the record length in years.

We have also added a new header line to indicate the overall record quality, to aid the range of users of GESLA. A brief, qualitative expert judgment assessment was made by visually inspecting every record in GESLA-3. Based on this evaluation, we now indicate if that record has: (1) no obvious issues; (2) possible datum issues; (3) possible quality control issues; and (4) possible datum and quality control issues. In total, 4747 records are classified as no obvious issues, 149 as having possible datum issues, 179 as having possible quality control issues, and 46 as having possible datum and quality control issues. Users who want to assess trends in extreme sea levels might, for example, only use long records identified to have no obvious issues. By contrast, users who are interested in shorter time periods (e.g., for hydrodynamic model validation or investigation of a specific event) might choose to use all available records.

In GESLA-3 we have added many new records located in the upper reaches of estuaries and tidally influenced rivers, and we hope these new records may help spur scientific innovation in these dynamic, highly anthropogenically-affected regions (see reviews by Hoitink and Jay, 2016; Haigh et al., 2020; and Talke and Jay, 2020). To aid in analysis, another new header line has therefore been added to indicate the hydrographic environment of the tidegauge location. This header line denotes whether a record is associated with a: (1) coastal; (2) river; or (3) lake, environment. We visually inspected each record, and location, and distinguished between 'coastal' and 'river' stations based on whether the water level signal was clearly dominated by tidal or river influences, considering distance from the open coastline. 'River' stations were classified as those where a strong river influence is evident in the water levels (and they are often some distance from the open coastline), whereas 'coastal sites' were classified as those where the tidal component was clearly dominant. As mentioned earlier, if a record had no clear tidal signal, for at least part of the year, it was removed. Lake stations are in regions hydraulically disconnected from the ocean. The lake sites are mostly in the Great Lakes (from NOAA or MEDS), although a small selection of sites are in the Ijsselmeer in the Netherlands (from RWS). We realise the subdivision into 'coastal' and 'river' is very difficult, and somewhat subjective, but we hope this is useful for users of the dataset. In total, 4159 records are classified as coastal, 784 as river and 178 as lake. Users only 


\section{*** Please note that this is an EarthArXiv preprint and not peer-reviewed. This work is provided by the authors as a means to ensure timely dissemination of scholarly work on a non-commercial basis. $* * *$}

323

interested in assessing trends in extreme sea levels from oceanographic sources may wish to just select the coastal records, and ignore the records associated with river and lake stations.

In each file, the data itself is comprised of five columns, separated by one or more spaces, consistent with GESLA-1 and GESLA-2. These are: (1) the date; (2) time; (3) the observed sea level; (4) the quality control flag; and (5) the flag indicating whether the data should be used for analysis or not. Each data value in GESLA-3 has been assigned two flags. The first flag (in column 4) indicates the quality control undertaken by the provider. For this we use the following flags to be consistent with GESLA-1 and GESLA-2: 0 for no quality control; 1 for correct value; 2 for interpolated value; 3 for doubtful value; 4 for isolated spike or wrong value, and 5 for missing value (set to -99.9999). Where available, we matched each of the provider flags to our system. Due to the huge effort it would require, we did not undertake a further extensive quality control of our own. However, we did visually inspect each record individually, and we manually flagged suspect values that were clearly outside of the normal range or were isolated spikes. It is clear that data quality is poor for some sources, and datum jumps do exist, and users should treat these particular records with caution. As discussed earlier the overall record quality identifies the records that should be treated with caution. The second flag (in column 5) is a 1 or 0 , indicating whether that value should be used for analysis, or not, respectively. All values whose quality control flag was 0,1 or 2 were set to analysis flag 1 (use), and all values whose quality control flag was 3,4 or 5 , were set to analysis flag 0 (do not use).

The name of each file is made up of the (lower case) site name, site code, country code, and an abbreviation of the contributor name (note, for the DA records, we have added an underscore and the initials of the person who provided that record, e.g., da_mm for the three records provided by Marta Marcos), separated by a hyphen (e.g., brest-822a-fra-uhslc). We have replaced all spaces in site names with an underscore. We have also removed all full stops, commas, brackets, accents, hyphens and other special characters from file names and site codes. Hence, the file name and code might not exactly match that of the data provider. For country codes we use the three letter ISO 3166-1 alpha-3 codes (https://en.wikipedia.org/wiki/ISO_3166-1_alpha-3).

\subsection{Data License}




\section{*** Please note that this is an EarthArXiv preprint and not peer-reviewed. This work is provided by the authors as a means to ensure timely dissemination of scholarly work on a non-commercial basis. $* * *$}

354 The developers of GESLA-1 only used data that had been provided to them on a personal basis, knowing how it was intended to be used. The dataset was subsequently made available only to trusted scientific users. For GESLA-2, the team divided the dataset into 27 'public' and 3 'private' sub-sets. Subject to acknowledgment of the data owner, the 'public' data set was readily available to download from the GESLA website and could be used for both research and consultancy purposes. However, the 'private' dataset could only be used for research, and not consultancy. This could only be obtained from the GESLA website with a password; bona fide researchers had to contact the GESLA team with an explanation of why they would like access to the dataset, in order to be given the password.

To simplify the process, we have decided not to separate the GESLA-3 data into two sets, on the GESLA website. Instead, we have examined the licenses associated with each data contributor, where available, included a link to the specific license in Table 1, and trust the users to comply with the license conditions. Table 1 also lists whether the data can be freely used for research and/or consultancy. For example, users wishing to use the records provided by $\mathrm{CV}, \mathrm{UZ}$ and CMEMS for consultancy purposes, must contact these organisations to obtain permission first (or in the case of CMEMS the organisations that provided the data to them). In GESLA-2 the Australia records were included in the 'private' sub-set. However, we are pleased that in GESLA-3 permission has been obtained to make these Australian records publicly available.

In summary, the data are accessible, but are covered by several different licences, some of which are non-commercial, by-attribution, or a combination of conditions. Access to the data does not currently require authentication, so restricted data are open to all, and we ask users to comply with the licence conditions. In acknowledgment of the central role of the UHSLC dataset in GESLA-3 (and earlier versions) and the decades-long effort to collect and quality assess the UHSLC data, we request that users of GESLA-3 data cite Caldwell et al. (2015) in addition to this paper in their work.

\subsection{Data Principles}

While constructing this third version of GESLA, we carefully considered the FAIR data principles, conceived by Wilkinson et al. (2016); that is that data should be findable, accessible, interoperable and reusable. These principles also help ensure that proper credit is given to all 


\section{*** Please note that this is an EarthArXiv preprint and not peer-reviewed. This work is provided by the authors as a means to ensure timely dissemination of scholarly work on a non-commercial basis. $* * *$}

those involved in the data lifecycle. In GESLA-3, we have implemented several improvements compared to GESLA-2, to move the dataset towards being FAIR-compliant. The data archived with the BODC Published Data Library (PDL) has been assessed against the GO-FAIR criteria (https://www.go-fair.org/fair-principles/) and at the time of writing, partially meets the criteria. The GESLA-3 data are assigned a globally unique and persistent identifier and the metadata contain the identifier of the data (the DOI universally unique identifier, UUID, is given on the landing page). The datasets are findable in searchable resources, such as Google Dataset Search and included in metadata directories (e.g., the European Directory of Marine Environmental). The file header metadata have been improved since GESLA-2 as we have differentiated between who has contributed the data (\# CONTRIBUTOR) and where the data originated from (\# ORIGINATOR), but in the next version we could look to implement more of the minimum mandatory metadata as detailed in the EuroSea deliverable D3.3 (Pérez Gómez et al, 2021).

We are working towards making the GESLA-3 data more interoperable. We have started to implement the use of some controlled vocabularies (e.g., ISO 3166-1 alpha-3 for country code), but in future versions we would like to include controlled vocabularies for other metadata. These would include using vocabularies such as the Research Organization Registry (https://ror.org) or the European Directory of Marine Organisations (https://edmo.seadatanet.org) for organisations, and SeaDataNet (https://www.seadatanet.org) for coordinate and datum information. The data can easily be converted into NetCDF (Network Common Data Form) files, and we hope to archive and distribute these data via an ERDDAP data server in future, where allowable. We have also provided computer scripts on the GESLA website in a variety of programming languages (e.g., MATLAB, Python and R), to allow users to easily load in the dataset for scientific analysis.

\section{DATASET ACCESS}

The 5,119 records in GESLA-3, and copies of the earlier two versions of the dataset, can be obtained from https://www.gesla.org. Furthermore, we now also provide a comma-delimited ASCII file containing information about each record and a Keyhole Markup Language (KML) file, which can be opened, for example, in Google Earth, to show record locations and information. On the GESLA website we keep a list of any problems that we, or others, identify with the data, which we subsequently correct. 
***Please note that this is an EarthArXiv preprint and not peer-reviewed. This work is provided by the authors as a means to ensure timely dissemination of scholarly work on a non-commercial basis. ${ }^{* * *}$

The GESLA-3 dataset has also been archived with the BODC (include link here).

\section{4. DISCUSSION AND CONCLUSIONS}

419 This paper has described the assembly of the third version of the GESLA dataset. GESLA-3 is 420 a major update, containing 91,021 years of sea-level observations, more than double that of 421 GESLA-2. The 5,119 records in GESLA-3 are nearly four times the number of that in GESLA-

422 2. Many of the records are now available to October 2021, encompassing an extra 6 or 7 years 423 of data compared to GESLA-2. Furthermore, new records have been added, improving spatial coverage, especially in North America, Europe, Japan and Australia. In particular, we have added many new records for stations located in the upper reaches of estuaries and tidally influenced rivers.

There is some duplication between records provided by the different sources. For example, a record for Brest is provided by UHSLC, REFMAR and CMEMS, and the data for Newlyn is provided by UHSLC, BODC and CMEMS. Some duplicate records may be present in USGS and CDWR data, or NOAA and USGS. In some cases, two agencies may operate gauges within several km of each other (e.g., the USGS and NOAA at Vancouver, Washington, or USGS and NOAA at Fort Pulaski, Georgia). The level of quality control may also differ between providers and the data lengths might not be consistent (e.g., the UHSLC and BODC dataset for Newlyn start in 1915 whereas the CMEMS record starts in 1990). At a tide gauge site with more than one record, we advise users to utilize the longest record, and preferably also the most up-to-date; a complementary strategy would be to use the agency giving the most attention to data quality (e.g., UHSLC in many cases) or the agency with the most experience measuring sea level (e.g., in a US context it is likely that NOAA has the most experience measuring sea level). Our choice to minimize data processing, and remain as consistent as possible with the originating agency, provides more freedom, but also puts more responsibility on the end-user. We recommend, therefore, that researchers do due diligence and carry out additional quality assurance that is commensurate with their goals and needs. We are in the process of making a list of the tide gauge sites with duplicate records, and will make this available on the GESLA website in the future. We also hope to add derived products in the future (e.g., time-series of astronomical tides and skew surges, etc.). 


\section{*** Please note that this is an EarthArXiv preprint and not peer-reviewed. This work is provided by the authors as a means to ensure timely dissemination of scholarly work on a non-commercial basis. $* * *$}

Despite the large improvement in the number of records and the number of years available, further improvements in the GESLA database are possible and desirable. As Woodworth et al. (2017) pointed out, GESLA-2 did not contain any data from India, for example, and there are only a few Bangladesh, Russian and Chinese sites made available via UHSLC. Mean sea-level data are available via PSMSL for these countries, but higher-frequency data are not distributed to the international community. A number of data series are only available commercially (e.g., from the National Mapping and Resource Information Authority (NAMRIA) in the Philippines or the Mekong Commission in Vietnam), and are therefore not included in GESLA-3. For example, only a fraction of the more than 1000 years of data from the Philippines, spread over $>50$ stations, are available in GESLA-3 (through the UHSLC data set), though data can be purchased. Coverage across South America and Africa could also be better, although this primarily reflects a smaller number of operational stations rather than lack of access to data. Additional records exist even in regions with high data coverage, for example for the Mississippi Delta from the US Army Corps of Engineers, or German authorities along the Ems River Estuary. Earlier digital records from our providers (Table 1 and 2) are often unavailable online. For example, many USGS records from pre-2007 are unavailable (e.g., from Florida) due to uncertain datum control. In Germany, many digital records are only in high water/low water format and are unavailable online; a similar issue exists for data archaeology efforts (such as the high water/low water record from 1875 to the present made available in Ralston

465

466 et al., 2019). In the future, the GESLA effort may therefore include a separate database for high water/low water or irregularly measured data, since these are often critical for assessing longterm trends in extremes (e.g., Dangendorf et al., 2013). Continued data archaeology efforts are needed; a number of records remain in non-electronic format, even up to the 1980's, sometimes in formats only readable by specialized machines (e.g., Talke and Jay, 2017). Many thousands of years of additional records remain to be digitized, quality assured, and published from around the Pacific Rim, North America, and Europe (e.g., Talke and Jay, 2013; 2017; Bradshaw et al., 2015; Pouvreau, 2008). Many historical records in other countries likely remain undocumented, undigitized, or otherwise unavailable. As these records become available, they will be added to the GESLA-3 database. Therefore, sea-level data archaeology efforts remain vital for improving $19^{\text {th }}$ and $20^{\text {th }}$ century data coverage.

Due to the time-consuming nature of this work, updates to GESLA have been made in 5 or 6-year intervals. Because data providers have recently made it easier to obtain datasets via 


\section{***Please note that this is an EarthArXiv preprint and not peer-reviewed. This work is provided by the authors as a means to ensure timely dissemination of scholarly work on a non-commercial basis.***}

478 website downloads or API's, we now hope to update the records more frequently. We also

479 hope to continue to add new records from additional data providers, as we become aware of 480 them. In GESLA-3, we have added, for the first time, 29 records captured recently from 481 exercises in data archaeology; in the future, we hope to add many more records of this nature. 482 We ask the readers and encourage data providers to contact us with details of any higher483 frequency records that are available, but not currently in GESLA; we will endeavour to include 484 these in future releases. As mentioned earlier, we also hope in the future to make GESLA data 485 available via an ERDDAP data server.

486 While assembling GESLA-3, we became aware of a new sea-level dataset that has recently been assembled called MISELA (Minute Sea-Level Analysis) (Zemunik et al., 2021). This contains 1-minute sea-level data, at 331 tide gauges worldwide, required for studying oceanographic processes like seiches, meteotsunamis, and infragravity and coastal waves. We welcome this new dataset. Combined, the PSMSL, GESLA and MISELA databases now allow for assessments of sea-level change across the full spectrum of frequencies of interest.

492 In concluding their paper, Woodworth et al. (2017) noted that the two scientists (Philip 493 Woodworth and John Hunter), who provide the bulk of the construction of GESLA-2, had now retired. Now, under new leadership, the GESLA initiative continues, and the number of studies that use GESLA continues to grow. We are confident that further advances in understanding of ocean tides, storm surges, extreme sea levels and other relevant coastal processes will stem

497 from this new release and enhance insight into how coastal communities might respond to sea498 level rise, extreme events and climate change. 
***Please note that this is an EarthArXiv preprint and not peer-reviewed. This work is provided by the authors as a means to ensure timely dissemination of scholarly work on a non-commercial basis. ${ }^{* * *}$

500

501

502

503

504

505

506

507

508

509

510

511

512

513

514

515

516

517

518

519

520

521

522

523

\section{4}

525

526

527

\section{ACKNOWLEDGMENTS}

We would like to wholeheartedly thank the data centres (listed in Table 1) and multiple individuals who provided the data in GESLA-3. We would specifically like to thank Andrew Matthews, Begoña Pérez Gómez, Marta de Alfonso Alonso-Muñoyerro, Angela Hibbert, Vibeke Huess, Ulpu Leijala, Guðmundur Birkir, Guy Westbrook, Torbjørn Taskjelle, Ruth Farre, Todd Ehret, Patrick Caldwell, Laurent Testut, Gerard McCarthy, Jenny Chiu, Chris Hughes, Ole Baltazar Andersen, Oleg Nikitin, Per Knudsen, Petra Zemunik, Thomas Dhoop, Charlie Thompson, and Scott Stephens (we are sorry if we have inadvertently missed anyone), for providing data or advice on various data related issues. The authors are grateful to Maritime Safety Queensland, Manly Hydraulics Laboratory, Victorian Regional Channels Authority, Western Australia Department of Transport, Victorian Ports Corporation Melbourne, Tasmanian Ports Corporation, Pilbara Ports Authority, Gippsland Ports, HydroSurvey (Flinders Ports) and Fremantle Ports for providing ongoing raw tide gauge data to the Bureau of Meteorology, which provides the basis for the quality-controlled hourly-resolution Australian contribution to GESLA-3.

We received no direct funding to assemble GESLA 3, however part of our time was funded on relevant grants, as follows: IDH time was partly funded via the NERC funded CHANCE Project (NE/S010262/1); SAT was partly funded by the National Science Foundation (Award number 1455350 and2013280); MM was supported by FEDER/Ministerio de Ciencia, Innovación y Universidades - Agencia Estatal de Investigación through the MOCCA project (grant no. RTI2018-093941-B-C31); PRT was supported by the NOAA Global Ocean Monitoring and Observation Program via the University of Hawai' $i$ Sea Level Center (grant no. NA11NMF4320128).

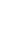

\section{CONFLICTS OF INTEREST}

The authors declare no conflicts of interest. 
***Please note that this is an EarthArXiv preprint and not peer-reviewed. This work is provided by the authors as a means to ensure timely dissemination of scholarly work on a non-commercial basis. $* * *$

\section{REFERENCES}

Arns, A., Wahl, T., Wolff, C., Vafeidis, A.T., Haigh, I.D., Woodworth, P., Niehüser, S. and Jensen, J, (2020). Non-linear interaction modulates global extreme sea levels, coastal flood exposure, and impacts. Nature Communications, 11, 1918, doi:10.1038/s41467020-15752-5.

Bradshaw, L. Rickards, L., Aarup, T., (2015). Sea level data archaeology and the Global Sea Level Observing System (GLOSS). GeoResJ, 6, 916. https://doi.org/10.1016/j.grj.2015.02.005.

Bromirski, P.D., Flick, R.E., \& Cayan, D.R. (2003). Storminess variability along the California coast: 1858-2000. Journal of Climate, 16(6), 982-993. https://doi.org/10.1175/15200442(2003)016<0982:SVATCC $>2.0 . \mathrm{CO} ; 2$

Caldwell, P.C., Merrifield, M.A. Thompson, P.R. (2015), Sea level measured by tide gauges from global oceans - the Joint Archive for Sea Level holdings (NCEI Accession 0019568), Version 5.5, NOAA National Centers for Environmental Information, Dataset, doi:10.7289/V5V40S7W.

Chant, R.J., Sommerfield, C.K., Talke, S.A., (2018). Impact of channel deepening on tidal and gravitational circulation in a highly engineered estuarine basin. Estuaries and Coasts 41(6), p. 1587-1600. https://doi.org/10.1007/s12237-018-0379-6.

Church, J.A., Clark, P.U., Cazenave, A., Gregory, J.M., Jevrejeva, S., Levermann, A., Merrifield, M.A., Milne, G.A., Nerem, R.S., Nunn, P.D., Payne, A.J., Pfeffer, W.T., Stammer, D., and Unnikrishnan, A.S., (2013). Sea Level Change. In: Climate Change 2013: The Physical Science Basis. Contribution of Working Group I to the Fifth Assessment Report of the Intergovernmental Panel on Climate Change [Stocker, T.F., D. Qin, G.-K. Plattner, M. Tignor, S.K. Allen, J. Boschung, A. Nauels, Y. Xia, V. Bex and P.M. Midgley (eds.)]. Cambridge University Press, Cambridge, United Kingdom and New York, NY, USA.

Dangendorf, S., Mudersbach, C., Wahl, T., Jensen, J. (2013). Characteristics of intra-, interannual and decadal sea-level variability and the role of meteorological forcing: the long record of Cuxhaven. Ocean Dynamics, 63, 209-224.

Familkhalili, R., Talke, S.A., (2016). The Effect of Channel Deepening on Storm Surge: A Case Study of Wilmington, NC. Geophysical Research Letters, 43(17), 9138-9147. DOI 10.1002/2016GL069494.

Fox-Kemper, B., Hewitt, H.T., Xiao, C., Aðalgeirsdóttir, G., Drijfhout S. S., Edwards, T. L., Golledge N.R., Hemer, M., Kopp, R.E., Krinner, G., Mix, A., Notz, D., Nowicki, S., Nurhati, I.S., Ruiz L., Sallée J-B., Slangen, A.B.A. Yu, Y., (2021). Ocean, Cryosphere and Sea Level Change. In: Climate Change 2021: The Physical Science Basis. Contribution of Working Group I to the Sixth Assessment Report of the Intergovernmental Panel on Climate Change [Masson-Delmotte, V., P. Zhai, A. Pirani, S. L. Connors, C. Péan, S. Berger, N. Caud, Y. Chen, L. Goldfarb, M. I. Gomis, M. Huang, K. Leitzell, E. Lonnoy, J.B.R. Matthews, T. K. Maycock, T. Waterfield, O. Yelekçi, R. Yu and B. Zhou (eds.)]. Cambridge University Press. In press.

Hague, B.S., Jones, D.A., Trewin, B., Jakob, D., Murphy, B., Martin, D., Braganza, K. (2021). ANCHORS: A multi-decadal tide gauge data sets to monitor Australian relative sea level changes, in press Geosci. Data. J. 


\section{*** Please note that this is an EarthArXiv preprint and not peer-reviewed. This work is provided by the authors as a means to ensure timely dissemination of scholarly work on a non-commercial basis.***}

Haigh et al. (2009). Mean sea level trends around the English Channel over the 20th century and their wider context. Continental Shelf Research, 29, 2083-2098.

Haigh, I.D. et al. (2020). The tides they are a' changing: A comprehensive review of past and future non-astronomical changes in tides, their driving mechanisms and future implications. Reviews of Geophysics, 58(1), e2018RG000636. https://doi.org/10.1029/2018RG000636.

Hoitink, A.J.F., Jay, D.A. (2016), Tidal river dynamics: Implications for deltas, Rev. Geophys., 54, 240-272. doi:10.1002/2015RG000507.

Holgate, S.J., Matthews, A., Woodworth, P.L., Rickards, L.J., Tamisiea, M.E., Bradshaw, E., Foden, P.R., Gordon, K.M, Jevrejeva, S., Pugh, J., (2013). New Data Systems and Products at the Permanent Service for Mean Sea Level. Journal of Coastal Research, 29 (3), 493-504. https://doi.org/10.2112/JCOASTRES-D-12-00175.1.

Hunter, J.R., Church, J.A., White, N.J., Zhang, X., (2013). Towards a global regionally varying allowance for sea-level rise. Ocean Engineering, 71, 17-27, doi:10.1016/j.oceaneng.2012.12.041.

Hunter, J.R., Woodworth, P.L., Wahl, T. Nicolls, R.J., (2017). Using global tide gauge data to validate and improve the representation of extreme sea levels in flood impact studies. Global and Planetary Change, 156, 34-45, doi:10.1016/j.gloplacha.2017.06.007.

Marcos, M., Puyol. B., Calafat, F.M., Woppelmann, G., (2013). Sea level changes at Tenerife Island (NE Tropical Atlantic) since 1927, J. Geophys. Res. Oceans, 118, doi:10.1002/jgrc. 20377.

Marcos, M; Puyol, B., Calafat, F.M., Woppelmann, G., (2013). Sea level changes at Tenerife Island (NE Tropical Atlantic) since 1927. Journal of Geophysical Research: Oceans, 118 (10). 4899-4910. 10.1002/jgrc.20377.

Marcos, M., Calafat, F. M., Berihuete, Á., Dangendorf, S. (2015). Long-term variations in global sea level extremes. J. Geophys. Res. Oceans, 120, 8115- 8134, doi:10.1002/2015JC011173.

Marcos, M., Woodworth, P.L. (2017). Spatio-temporal changes in extreme sea levels along the coasts of the North Atlantic and the Gulf of Mexico. Journal of Geophysical Research Oceans, 122, doi:10.1002/2017JC013065.

Marcos, M., Puyol, B. Amores A., Pérez Gómez, B., Fraile, M.Á., Talke, S.A., (2021). Historical tide gauge sea-level observations in Alicante and Santander (Spain) since the 19th century. Geosc. Data J., doi: 10.1002/gdj3.112.

Menendez, M., Woodworth, P.L. (2010). Changes in extreme high water levels based on a quasi-global tide-gauge dataset. Journal of Geophysical Research, 115, C10011, doi:10.1029/2009JC005997.

Mawdsley, R.J., Haigh, I.D. and Wells, N.C. (2015). Global secular changes in different tidal high water, low water and range levels. Earth's Future, 3, doi:10.1002/2014EF000282.

Muis, S., Irazoqui Apecechea, M., Dullaart, J., de Lima Rego, J., Madsen, K.S., Su, J., Yan, K. and Verlaan, M., (2020). A high-resolution global dataset of extreme sea levels, tides, and storm surges, including future projections. Frontiers in Marine Science, 7:263, doi:10.3389/fmars.2020.00263. 


\section{*** Please note that this is an EarthArXiv preprint and not peer-reviewed. This work is provided by the authors as a means to ensure timely dissemination of scholarly work on a non-commercial basis. ***}

Oppenheimer et al., (2019). Sea Level Rise and Implications for Low Lying Islands, Coasts and Communities. Chapter 4 in In: IPCC Special Report on the Ocean and Cryosphere in a Changing Climate [H.O.Pörtner, D.C.Roberts, V.MassonDelmotte, P.Zhai,M.Tignor, E.Poloczanska, K.Mintenbeck, A.Alegría, M.Nicolai, A. Okem, J. Petzold, B. Rama, N.M. Weyer (eds.)]. https://www.ipcc.ch/srocc/.

Peng, D., Hill, E.M., Meltzner, A.J. and Switzer, A.D., (2019). Tide gauge records show that the 18.61-year nodal tidal cycle can change high water levels by up to $30 \mathrm{~cm}$. JGR Oceans., 124 (1), 736-749, doi:10.1029/2018JC014695.

Pérez Gómez, B., Testut, L., Hibbert, A., Matthews, A., et al., (2021). EuroSea Deliverable D3.3: New Tide Gauge Data Flow Strategy. https://eurosea.eu/download/outputs_and_reports/deliverables/EuroSeaD3.3_New_Tide_Gauge_Data_Flow_Strategy.pdf,

Piccioni, G. et al. (2018). Coastal improvements for tide models: the impact of ALES retracker. Remote Sensing, 10, 700, doi:10.3390/rs10050700.

Piccioni, G., Dettmering, D., Bosch, W., Seitz, F., (2019). TICON: TIdal CONstants based on GESLA sea-level records from globally located tide gauges. Geoscience Data Journal, doi:10.1002/gdj3.72.

Pouvreau, N., (2008). Trois cents ans de mesures marégraphiques en France: outils, méthodes et tendances des composantes du niveau de la mer au port de Brest. Ph.D. thesis, Universite de La Rochelle

Ralston, D.K., Talke, S.A., Geyer, W.R., Al'Zubadaei, H., Sommerfield, C.K., (2019). Bigger tides, less flooding: Effects of dredging on water level in the Hudson River estuary. Journal of Geophysical Research, 124(1), doi: 10.1029/2018JC014313.

Rashid, M.M., Wahl, T., Chambers, D.P., (2021). Extreme sea level variability dominates coastal flood risk changes at decadal time scales. Environmental Research Letters, 16, 024026 .

Ray, R.D., (2020). First global observations of third-degree ocean tides. Science Advances, 6, eabd4744.

Ray, R., S.A Talke (2019). Nineteenth-Century Tides in the Gulf of Maine and implications for secular trends. Journal of Geophysical Research https://agupubs.onlinelibrary.wiley.com/doi/abs/10.1029/2019JC015277.

Rhein, M., S.R. Rintoul, S. Aoki, E. Campos, D. Chambers, R.A. Feely, S. Gulev, G.C. Johnson, S.A. Josey, A. Kostianoy, C. Mauritzen, D. Roemmich, L.D. Talley, F. Wang, (2013). Observations: Ocean. In: Climate Change 2013: The Physical Science Basis. Contribution of Working Group I to the Fifth Assessment Report of the Intergovernmental Panel on Climate Change [Stocker, T.F., D. Qin, G.-K. Plattner, M. Tignor, S.K. Allen, J. Boschung, A. Nauels, Y. Xia, V. Bex and P.M. Midgley (eds.)]. Cambridge University Press, Cambridge, United Kingdom and New York, NY, USA.

Santamaria-Aguilar, S., Vafeidis, A.T., (2019). Are extreme skew surges independent of high water levels in a mixed semidiurnal tidal regime? Journal of Geophysical Research, 123, 8877-8886, doi:10.1029/2018JC014282.

Schindelegger, M., Green, J.A.M., Wilmes, S.-B., Haigh, I.D. (2018). Can we model the effect of observed sea level rise on tides? Journal of Geophysical Research Oceans, 123, doi:10.1029/2018JC013959. 


\section{*** Please note that this is an EarthArXiv preprint and not peer-reviewed. This work is provided by the authors as a means to ensure timely dissemination of scholarly work on a non-commercial basis.***}

Shalowitz, A.L., (1962). Shore and sea boundaries: With special reference to the interpretation and use of coast and geodetic survey data (Vol. 1). Washington, DC: Government Printing Office.

Tadesse, M., Wahl, T., Cid, A., (2020). Data-driven modeling of global storm surges. Frontiers in Marine Science, 7:260, doi:10.3389/fmars.2020.00260.

Talke, S.A \& D.A. Jay (2013). Nineteenth Century North American and Pacific Tides: Lost or just forgotten? Journal of Coastal Research 29(6a), 118- 127.

Talke, S.A., D.A. Jay (2017). Archival Water-Level Measurements: Recovering Historical Data to Help Design for the Future. US Army Corps of Engineers: Civil Works Technical Series, Report CWTS-02, 49p.

Talke, S.A., D.A. Jay (2020). Changing tides: The role of natural and anthropogenic factors. Annual Review of Marine Science, 12, 121-151, https://doi.org/10.1146/annurevmarine-010419-010727

Talke, S.A., Orton P., Jay D.A., (2014). Increasing Storm Tides in New York Harbor, 18442013. Geophysical Research Letters, 41(9), 3149-3155, DOI: 10.1002/2014GL059574

Talke, S.A., Kemp, A., Woodruff, J., (2018). Relative sea level, tides, and extreme water levels in Boston (MA) from 1825 to 2018. Journal of Geophysical Research 123(6), doi.org/10.1029/2017JC013645

Talke, S.A., Mahedy, A., Jay, D.A., Lau, P., Hilley, C., Hudson, A., (2020). Sea level, tidal and river flow trends in the Lower Columbia River Estuary, 1853-present, Journal of Geophysical Research-Oceans. https://doi.org/10.1029/2019JC015656

Talke, S.A, Familkhalili, R., Jay D.A. (2021). The influence of channel deepening on tides, river discharge effects, and storm surge, Journal of Geophysical Research: Oceans: https://doi.org/10.1029/2020JC016328

Tsitsikas, C. (2018). Regional sea level allowances along the world coast-line. Master's Thesis, Utrecht University.

Wahl, T., Haigh, I.D., Nicholls, R.J., Arns, A., Dangendorf, S., Hinkel, J., Slangen, A.B.A., (2017). Understanding extreme sea levels for broad-scale coastal impact and adaptation analysis. Nature Communications, 16075.

Ward, P.J. Couasnon, A., Eilander, D., Haigh, I.D., Hendry, A., Muis, S., Veldkamp T.I.E, Winsemius, H.C., Wahl, T., (2018). Dependence between high sea-level and high river discharge increases flood hazard in global deltas and estuaries, Environmental Research Letters, 13, 084012, doi:10.1088/1748-9326/aad400.

Wilkinson, M., Dumontier, M., Aalbersberg, I. et al. (2016). The FAIR Guiding Principles for scientific data management and stewardship. Sci Data 3, 160018. https://doi.org/10.1038/sdata.2016.18

Wolff, C. et al. (2018). A Mediterranean coastal database for assessing the impacts of sea-level rise and associated hazards. Scientific Data, 5, 180044, doi:10.1038/sdata.2018.44.

Wong, P.P., Losada, I.J., Gattuso, J.-P., Hinkel, J., Khattabi A., McInnes K.L., Saito, Y., Sallenger, A., (2014). Coastal systems and low-lying areas. In: Climate Change 2014: Impacts, Adaptation, and Vulnerability. Part A: Global and Sectoral Aspects. Contribution of Working Group II to the Fifth Assessment Report of the Intergovernmental Panel on Climate Change [Field, C.B., V.R. Barros, D.J. Dokken, K.J. 
***Please note that this is an EarthArXiv preprint and not peer-reviewed. This work is provided by the authors as a means to ensure timely dissemination of scholarly work on a non-commercial basis. ***

Mach, M.D. Mastrandrea, T.E. Bilir, M. Chatterjee, K.L. Ebi, Y.O. Estrada, R.C. Genova, B. Girma, E.S. Kissel, A.N. Levy, S. MacCracken, P.R. Mastrandrea, and L.L. White (eds.)]. Cambridge University Press, Cambridge, United Kingdom and New York, NY, USA, pp. 361-409.

Woodworth, P.L., Hunter, J.R., Marcos, M., Caldwell, P., Menendez, M., Haigh, I.D., (2017). Towards a global higher-frequency sea level data set. Geoscience Data Journal, 3 (2), 5059. doi:10.1002/gdj3.42.

Woodworth, P.L. Hibbert, A., (2018). The nodal dependence of long-period ocean tides in the Drake Passage. Ocean Science, 14, 711-730, doi:10.5194/os-14-711-2018.

Woodworth, P.L., Melet, A. Marcos, M., Ray, R.D., Wöppelmann, G., Sasaki, Y.N., Cirano, M., Hibbert, A., Huthnance, J.M., Monserrat, S., Merrifield, M.A. (2019). Forcing Factors Affecting Sea Level Changes at the Coast, Surveys in Geophysics, 40, 13511397.

Woodworth, P.L., Hunter, J.R., Marcos, M., Hughes, C.W., (2021). Towards reliable global allowances for sea level rise. Global and Planetary Change, 203, 103522, https://doi.org/10.1016/j.gloplacha.2021.103522.

Zemunik, P., Šepić, J. Pellikka, H., Ćatipović, L. and Vilibić, I. (2021). Minute Sea-Level Analysis (MISELA): a high-frequency sea-level analysis global dataset. Earth System Science Data (ESSD), 13, 4121-4132. https://doi.org/10.5194/essd-13-4121-2021. 
***Please note that this is an EarthArXiv preprint and not peer-reviewed. This work is provided by the authors as a means to ensure timely dissemination of scholarly work on a non-commercial basis.***

Table 1: Information on data providers, licenses and data use. Grey shading indicates new data sources not in GESLA-2.

\begin{tabular}{|c|c|c|c|c|c|c|c|}
\hline 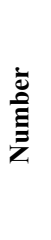 & 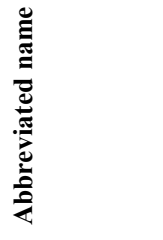 & 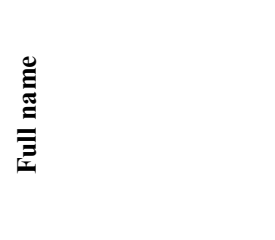 & 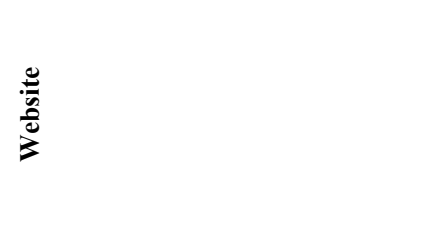 & 己̈ & 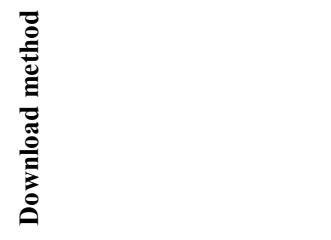 & 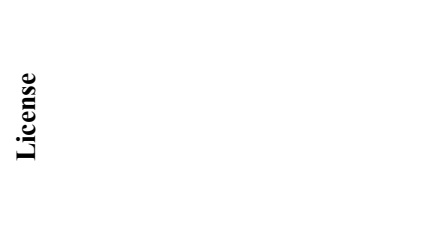 & $\stackrel{\mathscr{L}}{\infty}$ \\
\hline 1 & UHSLC & $\begin{array}{l}\text { University of Hawaii } \\
\text { Sea level Center }\end{array}$ & https://uhslc.soest.hawaii.edu & Global & $\begin{array}{c}\text { Downloaded each record } \\
\text { automatically via API } \\
\text { (ERDDAP server) }\end{array}$ & $\begin{array}{c}\text { Specified on website: } \\
\text { https://uhslc.soest.hawaii.edu/erddap/t } \\
\text { abledap/global_daily_rqds.html }\end{array}$ & $\begin{array}{l}\text { Research and } \\
\text { consultancy }\end{array}$ \\
\hline 2 & NOAA & $\begin{array}{c}\text { National Oceanic and } \\
\text { Atmospheric } \\
\text { Administration } \\
\end{array}$ & $\frac{\frac{\text { https://api.tidesandcurrents.noaa.go }}{\text { v/api/prod/ }}}{\underline{\text { and }}}$ & $\begin{array}{l}\text { United States of } \\
\text { America }\end{array}$ & $\begin{array}{l}\text { Downloaded each record } \\
\text { automatically via API }\end{array}$ & Unspecified & $\begin{array}{l}\text { Research and } \\
\text { consultancy }\end{array}$ \\
\hline 3 & CMEMS & $\begin{array}{l}\text { Copernicus Marine } \\
\text { Environment } \\
\text { Monitoring Service }\end{array}$ & 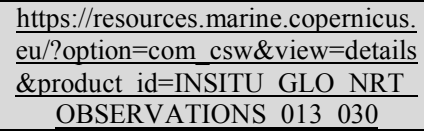 & Europe & $\begin{array}{l}\text { Download netcdf files } \\
\text { from ftp site }\end{array}$ & Specified in netcdf data files & $\begin{array}{c}\text { Research (for } \\
\text { consultancy contact } \\
\text { data owners } \\
\text { directly) } \\
\end{array}$ \\
\hline 4 & MEDS & $\begin{array}{l}\text { Marine Environmental } \\
\text { Data Section }\end{array}$ & $\begin{array}{l}\frac{\text { https://isdm-gdsi.gc.ca/isdm- }}{\text { gdsi/twl-mne/inventory- }} \\
\text { inventaire/index-eng.htm }\end{array}$ & Canada & $\begin{array}{l}\text { Downloaded each record } \\
\text { manually from website (in } \\
10 \text {-year blocks) }\end{array}$ & $\begin{array}{c}\frac{\text { Specified on website: }}{\text { https://www.qc.dfo- }} \\
\text { mpo.gc.ca/tides/en/licence-agreement }\end{array}$ & $\begin{array}{l}\text { Research and } \\
\text { consultancy }\end{array}$ \\
\hline 5 & USGS & $\begin{array}{c}\text { United States } \\
\text { Geological Survey }\end{array}$ & http://waterdata.usgs.gov/nwis/uv & $\begin{array}{c}\text { United States of } \\
\text { America }\end{array}$ & $\begin{array}{l}\text { Downloaded each record } \\
\text { manually from website }\end{array}$ & Unspecified & $\begin{array}{c}\text { Research and } \\
\text { consultancy }\end{array}$ \\
\hline 6 & BOM & $\begin{array}{c}\text { Bureau of } \\
\text { Meteorology }\end{array}$ & $\begin{array}{c}\text { http://www.bom.gov.au/oceanograp } \\
\text { hy/projects/abslmp/abslmp.shtml }\end{array}$ & $\begin{array}{c}\text { Australia and } \\
\text { Pacific Islands }\end{array}$ & $\begin{array}{c}\text { Obtained directly from } \\
\text { BOM }\end{array}$ & Unspecified & $\begin{array}{c}\text { Research and } \\
\text { consultancy }\end{array}$ \\
\hline 7 & RWS & Rijkswaterstaat & $\begin{array}{l}\text { https://opendap.deltares.nl/thredds/c } \\
\text { atalog/opendap/rijkswaterstaat/wate } \\
\text { rbase/27_Waterhoogte_in_cm_t.o.v. } \\
\text { normaal_amsterdams_peil_in_opp } \\
\text { ervlaktewater/nc/catalog.html }\end{array}$ & The Netherlands & $\begin{array}{l}\text { Downloaded each record } \\
\text { manually from website }\end{array}$ & Unspecified & $\begin{array}{l}\text { Research and } \\
\text { consultancy }\end{array}$ \\
\hline 8 & JODC_JMA & $\begin{array}{c}\text { Japan Oceanographic } \\
\text { Data Center, Japan } \\
\text { Meteorological } \\
\text { Agency } \\
\end{array}$ & $\frac{\underline{\text { https://jdoss1.jodc.go.jp/vpage/tide. }}}{\underline{\mathrm{html}}}$ & Japan & $\begin{array}{l}\text { Downloaded each site } \\
\text { manually from website (in } \\
10 \text {-year blocks) }\end{array}$ & $\begin{array}{c}\text { Specified on website: } \\
\text { https://jdoss1.jodc.go.jp/vpage/tide.ht } \\
\text { ml }\end{array}$ & $\begin{array}{l}\text { Research and } \\
\text { consultancy }\end{array}$ \\
\hline 9 & SMHI & $\begin{array}{c}\text { Swedish } \\
\text { Meteorological and } \\
\text { Hydrological Institute }\end{array}$ & $\begin{array}{c}\frac{\text { https://www.smhi.se/data/oceanogra }}{\text { fi/ladda-ner-oceanografiska- }} \\
\frac{\text { observationer/\#param=sealevelMin }}{\text { utes,stations=all }}\end{array}$ & Sweden & $\begin{array}{l}\text { Manually downloaded each } \\
\text { record from website. }\end{array}$ & $\begin{array}{c}\text { http://www.smhi.se/data/oppna- } \\
\text { data/information-om-oppna- } \\
\text { data/villkor-for-anvandning-1.30622 } \\
\end{array}$ & $\begin{array}{l}\text { Research and } \\
\text { consultancy }\end{array}$ \\
\hline 10 & REFMAR & $\begin{array}{l}\text { Réseaux de référence } \\
\text { des observations } \\
\text { marégraphiques } \\
\text { (Reference networks } \\
\text { for tidal observations) }\end{array}$ & $\underline{\mathrm{http}: / / \mathrm{refmar} . \text { shom.fr/en }}$ & France & $\begin{array}{l}\text { Downloaded each record } \\
\text { manually from website }\end{array}$ & Unspecified & $\begin{array}{l}\text { Research and } \\
\text { consultancy }\end{array}$ \\
\hline
\end{tabular}


*** Please note that this is an EarthArXiv preprint and not peer-reviewed. This work is provided by the authors as a means to ensure timely dissemination of scholarly work on a non-commercial basis. ${ }^{* * *}$

\begin{tabular}{|c|c|c|c|c|c|c|c|}
\hline 11 & BODC & $\begin{array}{l}\text { British Oceanographic } \\
\text { Data Centre }\end{array}$ & $\frac{\frac{\text { https: } / / \text { www.bodc.ac.uk } / \text { data/hosted }}{\text { data systems/sea level/uk tide ga }}}{\text { uge network/ }}$ & $\begin{array}{l}\text { United Kingdom } \\
\text { of Great Britain } \\
\text { and Northern } \\
\text { Ireland } \\
\end{array}$ & $\begin{array}{l}\text { Downloaded each record } \\
\text { manually from website }\end{array}$ & $\begin{array}{c}\text { https://www.nationalarchives.gov.uk/ } \\
\text { doc/open-government- } \\
\text { licence/version/2/ }\end{array}$ & $\begin{array}{l}\text { Research and } \\
\text { consultancy }\end{array}$ \\
\hline 12 & CDWR & $\begin{array}{l}\text { California Department } \\
\text { of Water Resources }\end{array}$ & $\underline{\mathrm{https}: / / \mathrm{cdec} . w a t e r . c a . g o v /}$ & $\begin{array}{c}\text { United States of } \\
\text { America }\end{array}$ & $\begin{array}{l}\text { Downloaded each record } \\
\text { manually from website }\end{array}$ & Unspecified & $\begin{array}{c}\text { Research and } \\
\text { consultancy }\end{array}$ \\
\hline 13 & JODC_JCG & $\begin{array}{l}\text { Japan Oceanographic } \\
\text { Data Center, Japan } \\
\text { Coast Guard } \\
\end{array}$ & $\frac{\underline{\text { https://joss1.jodc.go.jp/vpage/tide. }}}{\underline{\text { html }}}$ & Japan, Antarctica & $\begin{array}{l}\text { Downloaded each record } \\
\text { manually from website }\end{array}$ & $\begin{array}{c}\text { Specified on website: } \\
\text { https://jdoss1.jodc.go.jp/vpage/tide.ht } \\
\text { ml }\end{array}$ & $\begin{array}{l}\text { Research and } \\
\text { consultancy }\end{array}$ \\
\hline 14 & NHS & $\begin{array}{c}\text { Norwegian } \\
\text { Hydrographic Service }\end{array}$ & $\frac{\text { http://api.sehavniva.no/tideapi_en.ht }}{\underline{\mathrm{ml}}}$ & Norway & $\begin{array}{c}\text { Downloaded each record } \\
\text { automatically via API and } \\
\text { combined with historic } \\
\text { data obtained directly }\end{array}$ & $\frac{\text { https://creativecommons.org/licenses/ }}{\underline{\text { by/4.0/deed.en }}}$ & $\begin{array}{l}\text { Research and } \\
\text { consultancy }\end{array}$ \\
\hline 15 & JODC_GIAJ & $\begin{array}{c}\text { Japan Oceanographic } \\
\text { Data Center, } \\
\text { Geospatial } \\
\text { Information Authority } \\
\text { of Japan } \\
\end{array}$ & $\frac{\underline{\text { https://jdoss1.jodc.go.jp/vpage/tide. }}}{\underline{\text { html }}}$ & Japan & $\begin{array}{l}\text { Downloaded each record } \\
\text { manually from website }\end{array}$ & $\begin{array}{c}\text { Specified on website: } \\
\text { https://jdoss1.jodc.go.jp/vpage/tide.ht } \\
\mathrm{ml}\end{array}$ & $\begin{array}{l}\text { Research and } \\
\text { consultancy }\end{array}$ \\
\hline 16 & WSV & $\begin{array}{c}\text { Wasserstraßen-und } \\
\text { Schifffahrtsverwaltung } \\
\text { des Bundes (Federal } \\
\text { Waterway and } \\
\text { Shipping } \\
\text { Administration) } \\
\end{array}$ & $\frac{\underline{\text { https://www.kuestendaten.de/DE/dy }}}{\text { namisch/Funktionen/Liste der_vorh }}$ & Germany & $\begin{array}{l}\text { Downloaded each record } \\
\text { manually from website }\end{array}$ & Unspecified & $\begin{array}{l}\text { Research and } \\
\text { consultancy }\end{array}$ \\
\hline 17 & JODC_PAHB & $\begin{array}{l}\text { Japan Oceanographic } \\
\text { Data Center, Ports and } \\
\text { Harbours Bureau }\end{array}$ & $\frac{\underline{\text { https://joss1.jodc.go.jp/vpage/tide. }}}{\underline{\text { html }}}$ & Japan & $\begin{array}{l}\text { Downloaded each record } \\
\text { manually from website }\end{array}$ & $\begin{array}{c}\text { Specified on website: } \\
\text { https://jdoss1.jodc.go.jp/vpage/tide.ht } \\
\text { ml }\end{array}$ & $\begin{array}{l}\text { Research and } \\
\text { consultancy }\end{array}$ \\
\hline 18 & SFWMD & $\begin{array}{l}\text { South Florida Water } \\
\text { Management District }\end{array}$ & $\frac{\text { https://www.sfwmd.gov/science- }}{\text { data/dbhydro }}$ & $\begin{array}{c}\text { United States of } \\
\text { America }\end{array}$ & $\begin{array}{l}\text { Downloaded each record } \\
\text { manually from website }\end{array}$ & Unspecified & $\begin{array}{c}\text { Research and } \\
\text { consultancy }\end{array}$ \\
\hline 19 & ISPRA & $\begin{array}{l}\text { Instituto Superiore per } \\
\text { la Protezione e la } \\
\text { Ricerca Ambientale } \\
\text { (Higher Institute for } \\
\text { Environmental } \\
\text { Protection and } \\
\text { Research) }\end{array}$ & $\underline{\text { https://mareografico.it }}$ & Italy & $\begin{array}{l}\text { Downloaded each record } \\
\text { manually from website }\end{array}$ & N/A & $\begin{array}{l}\text { Research and } \\
\text { consultancy }\end{array}$ \\
\hline 20 & IEO & $\begin{array}{c}\text { Instituto Español de } \\
\text { Oceanografia (Spanish } \\
\text { Istitute of } \\
\text { Oceanography) }\end{array}$ & https://www.seadatanet.org & Spain & $\begin{array}{l}\text { Downloaded each record } \\
\text { manually from website }\end{array}$ & Unspecified & $\begin{array}{l}\text { Research and } \\
\text { consultancy }\end{array}$ \\
\hline 21 & DA & Data Archelogy & N/A & $\begin{array}{c}\text { United States of } \\
\text { America, Spain, } \\
\text { United Kingdom } \\
\text { of Great Britain } \\
\text { and Northern } \\
\text { Ireland }\end{array}$ & $\begin{array}{l}\text { Obtained directly from } \\
\text { authors }\end{array}$ & N/A & $\begin{array}{l}\text { Research and } \\
\text { consultancy }\end{array}$ \\
\hline
\end{tabular}


*** Please note that this is an EarthArXiv preprint and not peer-reviewed. This work is provided by the authors as a means to ensure timely dissemination of scholarly work on a non-commercial basis. ${ }^{* * *}$

\begin{tabular}{|c|c|c|c|c|c|c|c|}
\hline 22 & UNAM & $\begin{array}{l}\text { National Autonomous } \\
\text { University of Mexico }\end{array}$ & $\frac{\mathrm{http}: / / \text { www.mareografico.unam.mx// }}{\text { portal// }}$ & Mexico & $\begin{array}{l}\text { Downloaded each record } \\
\text { manually from website }\end{array}$ & $\begin{array}{c}\text { Specified on website } \\
\text { http://www.mareografico.unam.mx/po } \\
\text { rtal/ }\end{array}$ & $\begin{array}{l}\text { Research and } \\
\text { consultancy }\end{array}$ \\
\hline 23 & FMI & $\begin{array}{l}\text { Finnish } \\
\text { Meteorological } \\
\text { Institute }\end{array}$ & $\frac{\underline{\text { https://en.ilmatieteenlaitos.fi/downl }}}{\text { oad-observations }}$ & Finland & $\begin{array}{c}\text { Downloaded each record } \\
\text { manually from website (in } \\
15 \text {-year blocks) }\end{array}$ & $\begin{array}{l}\text { https://en.ilmatieteenlaitos.fi/open- } \\
\text { data-licence }\end{array}$ & $\begin{array}{l}\text { Research and } \\
\text { consultancy }\end{array}$ \\
\hline 24 & DMI & $\begin{array}{c}\text { Danish Meteorological } \\
\text { Institute }\end{array}$ & 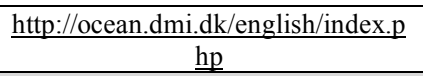 & Denmark & Data obtained directly & Unspecified & $\begin{array}{l}\text { Research and } \\
\text { consultancy }\end{array}$ \\
\hline 25 & BFG & $\begin{array}{l}\text { Bundesanstalt Für } \\
\text { Gewässerkunde } \\
\text { (Federal Institute of } \\
\text { Hydrology) }\end{array}$ & $\frac{\text { https://www.bafg.de/EN/03 The } \%}{\text { 20BfG/the bfg.html }}$ & Germany & Data obtained directly & Unspecified & $\begin{array}{l}\text { Research and } \\
\text { consultancy }\end{array}$ \\
\hline 26 & MI_C & $\begin{array}{l}\text { Marine Institute } \\
\text { (Coastal sites) }\end{array}$ & $\frac{\underline{\text { https://erddap.marine.ie/erddap/tabl }}}{\text { edap/IrishNationalTideGaugeNetwo }}$ & Ireland & $\begin{array}{l}\text { Downloaded each record } \\
\text { automatically via API } \\
\text { (ERDDAP server) }\end{array}$ & $\frac{\text { https://creativecommons.org/licenses/ }}{\underline{\text { by/4.0/ }}}$ & $\begin{array}{l}\text { Research and } \\
\text { consultancy }\end{array}$ \\
\hline 27 & $\mathrm{CCO}$ & $\begin{array}{l}\text { Coastal Channel } \\
\text { Observatory }\end{array}$ & $\frac{\underline{\text { https://coastalmonitoring.org/realti }}}{\underline{\text { medata/ }}}$ & $\begin{array}{l}\text { United Kingdom } \\
\text { of Great Britain } \\
\text { and Northern } \\
\text { Ireland } \\
\end{array}$ & $\begin{array}{l}\text { Downloaded each record } \\
\text { manually from website }\end{array}$ & $\frac{\underline{\text { https://www.nationalarchives.gov.uk/ }}}{\frac{\text { doc/open-government- }}{\underline{\text { licence/version/2/ }}}}$ & $\begin{array}{l}\text { Research and } \\
\text { consultancy }\end{array}$ \\
\hline 28 & NOC & $\begin{array}{l}\text { National } \\
\text { Oceanography Centre }\end{array}$ & $\underline{\text { https://noc.ac.uk }}$ & $\begin{array}{l}\text { United Kingdom } \\
\text { of Great Britain } \\
\text { and Northern } \\
\text { Ireland, Egypt, } \\
\text { Ukraine } \\
\end{array}$ & Data obtained directly & Unspecified & $\begin{array}{l}\text { Research and } \\
\text { consultancy }\end{array}$ \\
\hline 29 & NWFWMD & $\begin{array}{c}\text { North West Florida } \\
\text { Water Management } \\
\text { Department }\end{array}$ & $\begin{array}{l}\text { https://nwfwater.com/Data- } \\
\text { Publications/Hydrologic- } \\
\text { Data/Active-Stations-Map }\end{array}$ & $\begin{array}{l}\text { United States of } \\
\text { America }\end{array}$ & $\begin{array}{l}\text { Downloaded each record } \\
\text { manually from website }\end{array}$ & Unspecified & $\begin{array}{l}\text { Research and } \\
\text { consultancy }\end{array}$ \\
\hline 30 & ESEAS & $\begin{array}{l}\text { European Sea-Level } \\
\text { Service }\end{array}$ & $\frac{\text { https://www.bodc.ac.uk/projects/dat }}{\text { a management/european/eseas/ }}$ & $\begin{array}{c}\text { Poland, Turkey, } \\
\text { Croatia }\end{array}$ & Copied from GESLA2 & Unspecified & $\begin{array}{l}\text { Research and } \\
\text { consultancy }\end{array}$ \\
\hline 31 & ICG & $\begin{array}{c}\text { Icelandic Coast Guard } \\
\text { Hydrographic and } \\
\text { Maritime Safety } \\
\text { Department } \\
\end{array}$ & $\underline{\text { http://www.lhg.is/english/about-us/ }}$ & Iceland & Data obtained directly & Unspecified & $\begin{array}{l}\text { Research and } \\
\text { consultancy }\end{array}$ \\
\hline 32 & $\mathrm{UZ}$ & University of Zagreb & https://www.pmf.unizg.hr/geof/en\# & Croatia & Data obtained directly & Unspecified & $\begin{array}{c}\text { Research (for } \\
\text { consultancy contact } \\
\text { data owners } \\
\text { directly) } \\
\end{array}$ \\
\hline 33 & NCDEM & $\begin{array}{l}\text { North Carolina } \\
\text { Department of } \\
\text { Emergency } \\
\text { Management }\end{array}$ & https://www.ncdps.gov/ncem & $\begin{array}{l}\text { United States of } \\
\text { America }\end{array}$ & $\begin{array}{l}\text { Downloaded each record } \\
\text { manually from website }\end{array}$ & Unspecified & $\begin{array}{l}\text { Research and } \\
\text { consultancy }\end{array}$ \\
\hline 34 & $\mathrm{CV}$ & $\begin{array}{l}\text { City of Venice, Tide } \\
\text { Forecasts and } \\
\text { Reporting Center }\end{array}$ & $\frac{\text { https://www.comune.venezia.it/nod }}{\underline{\mathrm{e} / 6214}}$ & Italy & $\begin{array}{l}\text { Downloaded manually } \\
\text { from website }\end{array}$ & $\frac{\text { https://creativecommons.org/licenses/ }}{\text { by-nc-sa/3.0/it/ }}$ & $\begin{array}{l}\text { Research (for } \\
\text { consultancy contact } \\
\text { data owners } \\
\text { directly) } \\
\end{array}$ \\
\hline
\end{tabular}


***Please note that this is an EarthArXiv preprint and not peer-reviewed. This work is provided by the authors as a means to ensure timely dissemination of scholarly work on a non-commercial basis. ${ }^{* * *}$

\begin{tabular}{|c|c|c|c|c|c|c|c|}
\hline 35 & MI_R & $\begin{array}{l}\text { Marine Institute (River } \\
\text { Sites) }\end{array}$ & $\begin{array}{c}\text { https://erddap.marine.ie/erddap/tabl } \\
\text { edap/IrishNationalTideGaugeNetwo } \\
\text { rkRiverGauges.html }\end{array}$ & Ireland & $\begin{array}{l}\text { Automatically load in data } \\
\text { using ERDDAP }\end{array}$ & $\frac{\underline{\text { https://creativecommons.org/licenses/ }}}{\underline{\text { by/4.0/ }}}$ & $\begin{array}{l}\text { Research and } \\
\text { consultancy }\end{array}$ \\
\hline 36 & GLOSS & $\begin{array}{c}\text { Global Sea Level } \\
\text { Observing System }\end{array}$ & https://gloss-sealevel.org & Greenland & Copied from GESLA2 & Unspecified & $\begin{array}{l}\text { Research and } \\
\text { consultancy }\end{array}$ \\
\hline
\end{tabular}

Note: Bureau of Meteorology represent the same provider as National Tidal Centre Australia in Table 2 of Woodworth et al. (2017). 
*** Please note that this is an EarthArXiv preprint and not peer-reviewed. This work is provided by the authors as a means to ensure timely dissemination of scholarly work on a non-commercial

basis. ***

Table 2: Number of records and years of data for each data source.

\begin{tabular}{|c|c|c|c|c|c|c|c|c|c|c|c|c|}
\hline$\frac{\grave{d}}{\grave{\Xi}}$ & 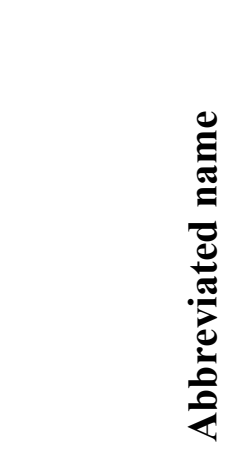 & 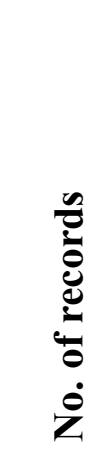 & 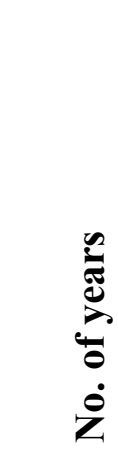 & 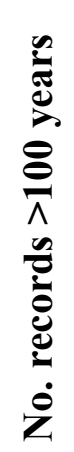 & 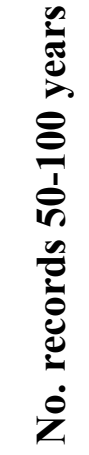 & 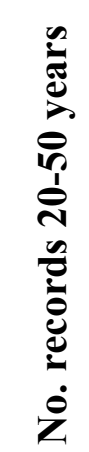 & 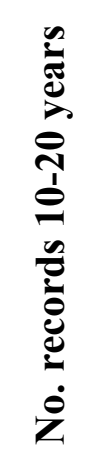 & 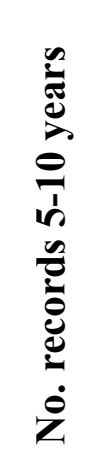 & 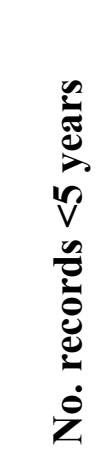 & $\begin{array}{l}\grave{\Xi} \\
\stackrel{\Xi}{\Xi} \\
\dot{\Xi}\end{array}$ & 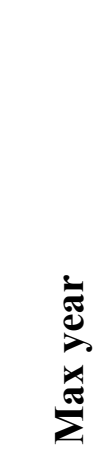 & 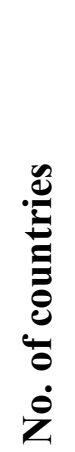 \\
\hline 1 & UHSLC & 692 & 17843 & 17 & 86 & 228 & 136 & 104 & 121 & 1846 & 2019 & 97 \\
\hline 2 & NOAA & 1395 & 14884 & 14 & 89 & 118 & 93 & 100 & 981 & 1897 & 2021 & 1 \\
\hline 3 & CMEMS & 590 & 9753 & 8 & 35 & 106 & 157 & 166 & 118 & 1886 & 2021 & 24 \\
\hline 4 & MEDS & 868 & 8761 & 7 & 63 & 57 & 49 & 63 & 629 & 1895 & 2021 & 1 \\
\hline 5 & USGS & 464 & 5314 & 0 & 0 & 23 & 263 & 118 & 60 & 1987 & 2021 & 1 \\
\hline 6 & BOM & 125 & 4603 & 2 & 26 & 85 & 11 & 1 & 0 & 1897 & 2020 & 14 \\
\hline 7 & RWS & 124 & 4482 & 4 & 17 & 54 & 27 & 12 & 10 & 1800 & 2018 & 1 \\
\hline 8 & JODC JMA & 81 & 3475 & 0 & 52 & 15 & 12 & 2 & 0 & 1960 & 2019 & 1 \\
\hline 9 & SMHI & 63 & 2547 & 9 & 11 & 8 & 18 & 13 & 4 & 1851 & 2021 & 1 \\
\hline 10 & REFMAR & 108 & 2479 & 2 & 10 & 30 & 40 & 14 & 12 & 1821 & 2021 & 1 \\
\hline 11 & BODC & 46 & 1879 & 1 & 14 & 28 & 3 & 0 & 0 & 1915 & 2021 & 1 \\
\hline 12 & CDWR & 98 & 1877 & 0 & 0 & 40 & 31 & 20 & 7 & 1982 & 2021 & 1 \\
\hline 13 & JODC JCG & 31 & 1667 & 0 & 22 & 9 & 0 & 0 & 0 & 1910 & 2019 & 2 \\
\hline 14 & NHS & 24 & 1503 & 2 & 15 & 6 & 1 & 0 & 0 & 1914 & 2020 & 1 \\
\hline 15 & JODC_GIAJ & 25 & 1402 & 0 & 15 & 10 & 0 & 0 & 0 & 1932 & 2019 & 1 \\
\hline 16 & WSV & 66 & 1262 & 0 & 0 & 44 & 10 & 11 & 1 & 1994 & 2020 & 1 \\
\hline 17 & JODC PAHB & 70 & 1117 & 0 & 2 & 20 & 24 & 23 & 1 & 1961 & 2019 & 1 \\
\hline 18 & SFWMD & 34 & 1090 & 0 & 1 & 26 & 7 & 0 & 0 & 1970 & 2020 & 1 \\
\hline 19 & ISPRA & 36 & 926 & 0 & 0 & 26 & 5 & 5 & 0 & 1971 & 2021 & 1 \\
\hline 20 & IEO & 12 & 714 & 0 & 10 & 1 & 1 & 0 & 0 & 1943 & 2015 & 1 \\
\hline 21 & $\mathrm{DA}$ & 29 & 685 & 1 & 3 & 10 & 3 & 3 & 9 & 1855 & 2019 & 3 \\
\hline 22 & UNAM & 35 & 663 & 0 & 2 & 14 & 6 & 4 & 9 & 1946 & 2018 & 1 \\
\hline 23 & FMI & 14 & 657 & 0 & 12 & 1 & 0 & 1 & 0 & 1971 & 2021 & 1 \\
\hline 24 & DMI & 3 & 331 & 2 & 1 & 0 & 0 & 0 & 0 & 1891 & 2020 & 1 \\
\hline 25 & BFG & 5 & 242 & 0 & 2 & 3 & 0 & 0 & 0 & 1917 & 2021 & 1 \\
\hline 26 & MI_C & 21 & 182 & 0 & 0 & 0 & 11 & 3 & 7 & 2006 & 2021 & 1 \\
\hline 27 & $\overline{\mathrm{CCO}}$ & 15 & 173 & 0 & 0 & 1 & 9 & 4 & 1 & 1996 & 2021 & 1 \\
\hline 28 & $\mathrm{NOC}$ & 7 & 137 & 0 & 0 & 3 & 4 & 0 & 0 & 1957 & 2018 & 3 \\
\hline 29 & NWFWMD & 9 & 100 & 0 & 0 & 0 & 5 & 4 & 0 & 2000 & 2021 & 1 \\
\hline 30 & ESEAS & 5 & 63 & 0 & 0 & 1 & 1 & 0 & 3 & 1935 & 2003 & 3 \\
\hline 31 & CG & 1 & 51 & 0 & 1 & 0 & 0 & 0 & 0 & 1970 & 2020 & 1 \\
\hline 32 & $\mathrm{UZ}$ & 1 & 44 & 0 & 0 & 1 & 0 & 0 & 0 & 1974 & 2017 & 1 \\
\hline 33 & NCDEM & 10 & 39 & 0 & 0 & 0 & 0 & 1 & 9 & 2013 & 2021 & 1 \\
\hline 34 & $\mathrm{CV}$ & 1 & 38 & 0 & 0 & 1 & 0 & 0 & 0 & 1983 & 2020 & 1 \\
\hline 35 & MI_R & 9 & 32 & 0 & 0 & 0 & 0 & 0 & 9 & 2018 & 2021 & 1 \\
\hline 36 & GLOSS & 2 & 6 & 0 & 0 & 0 & 0 & 0 & 2 & 1997 & 1999 & 1 \\
\hline- & Total & 5119 & 91021 & 69 & 489 & 969 & 927 & 672 & 1993 & 1800 & 2021 & 114 \\
\hline
\end{tabular}


*** Please note that this is an EarthArXiv preprint and not peer-reviewed. This work is provided by the authors as a means to ensure timely dissemination of scholarly work on a non-commercial basis. $^{* * *}$

Table 3: Example of a GESLA-3 data file (brest-822a-france-uhslc) containing header lines followed by the hourly sea level values from UHSLC. A full description of the format is given in https://www.gesla.org.

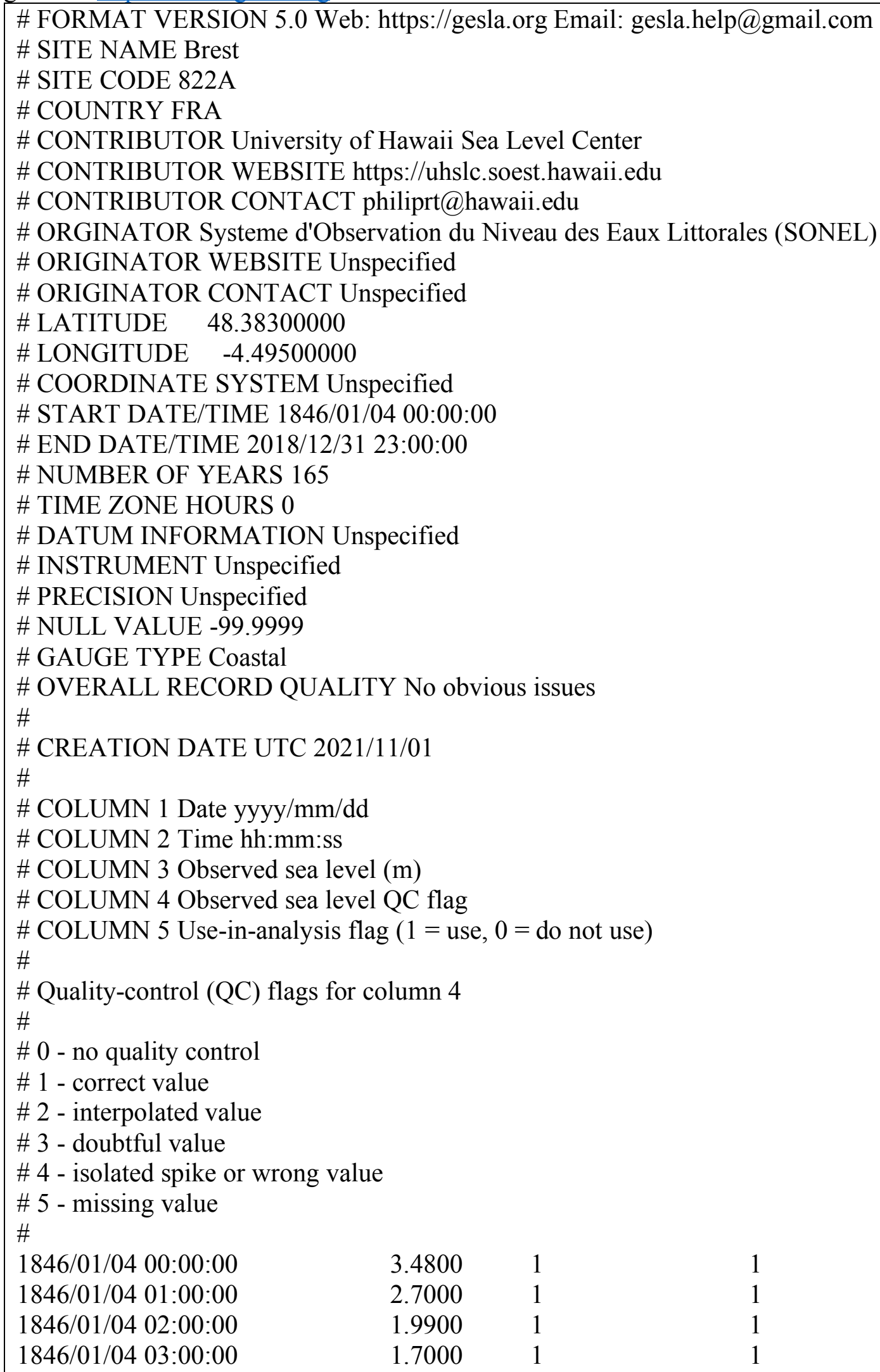


***Please note that this is an EarthArXiv preprint and not peer-reviewed. This work is provided by the authors as a means to ensure timely dissemination of scholarly work on a non-commercial basis. ${ }^{* * *}$

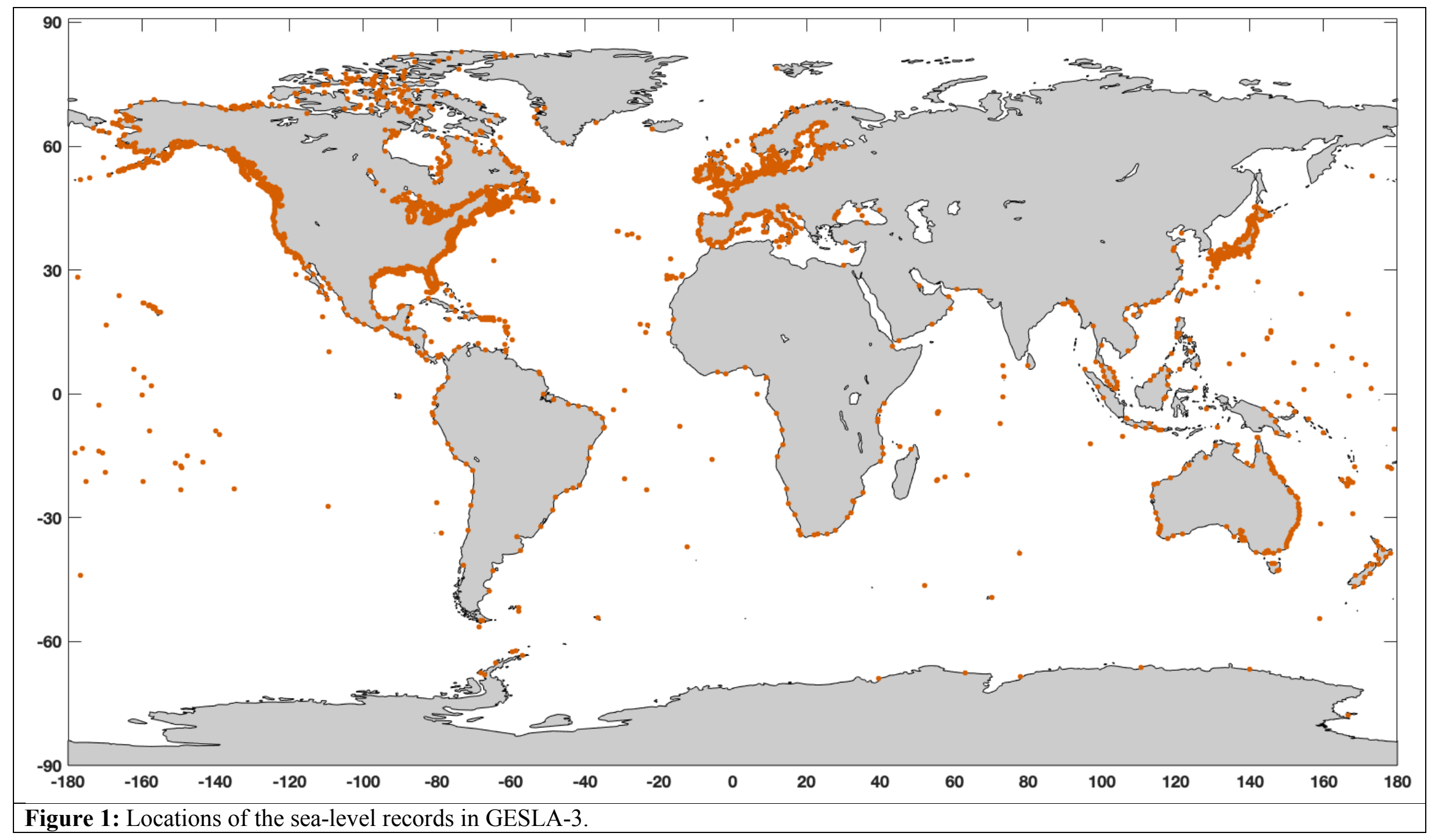



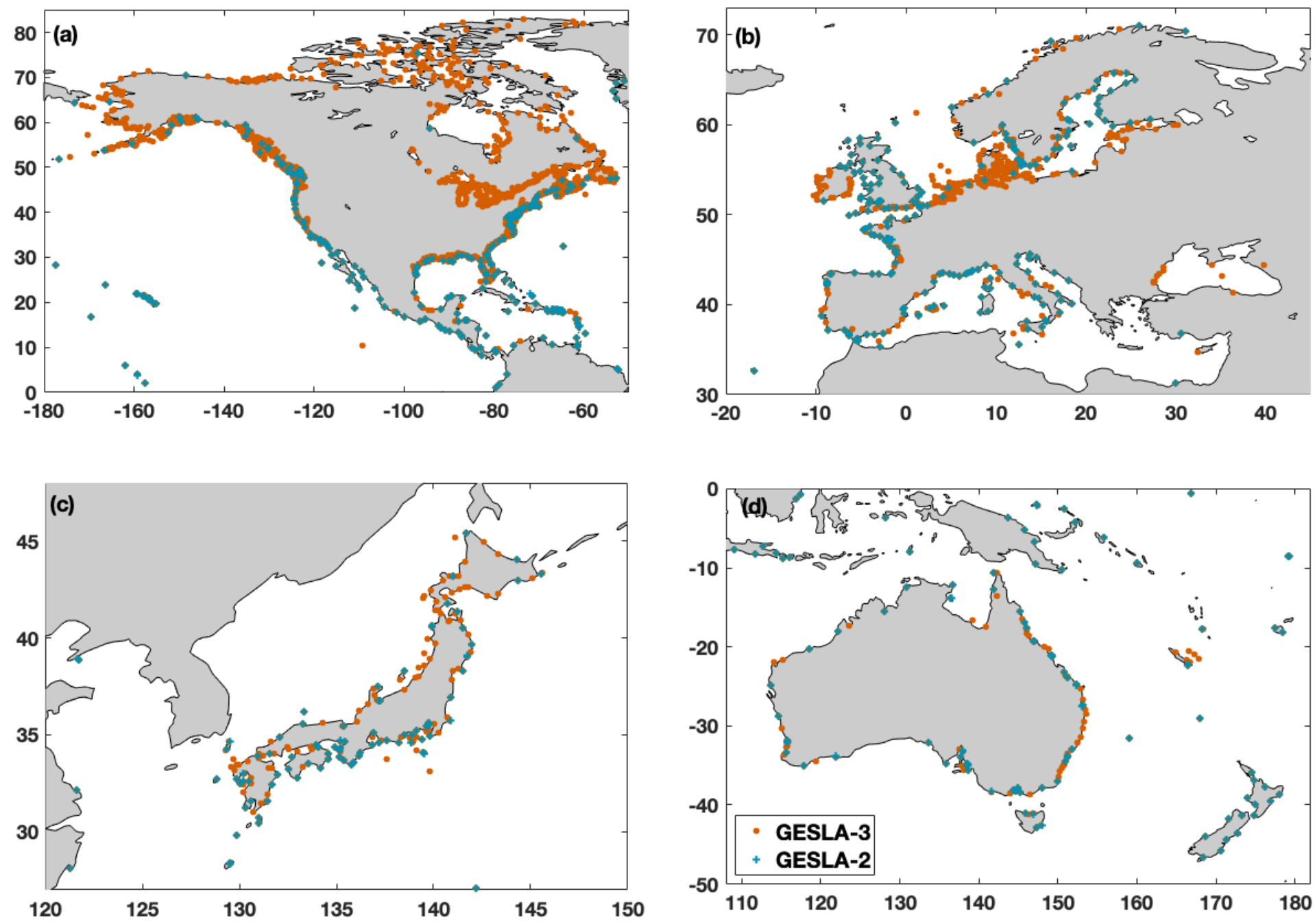

Figure 2: Locations of the sea-level records in GESLA-2 and GESLA-3 for the four regions with the greatest coverage increase: (a) North America; (b) Europe; (c) Japan and (d) Australia. Note the GESLA-2 locations are also in GESLA-3. 


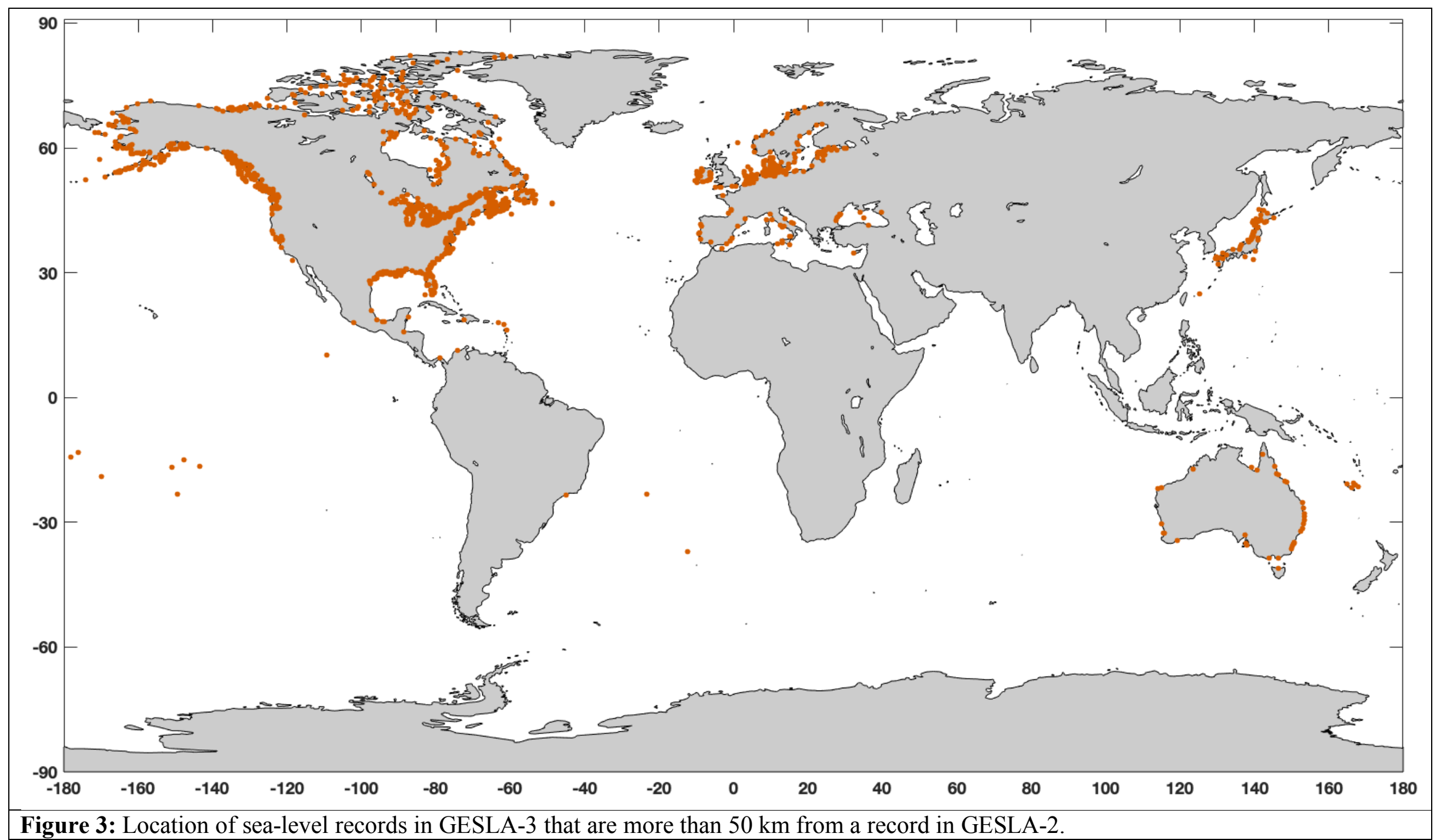


***Please note that this is an EarthArXiv preprint and not peer-reviewed. This work is provided by the authors as a means to ensure timely dissemination of scholarly work on a non-commercial basis.***
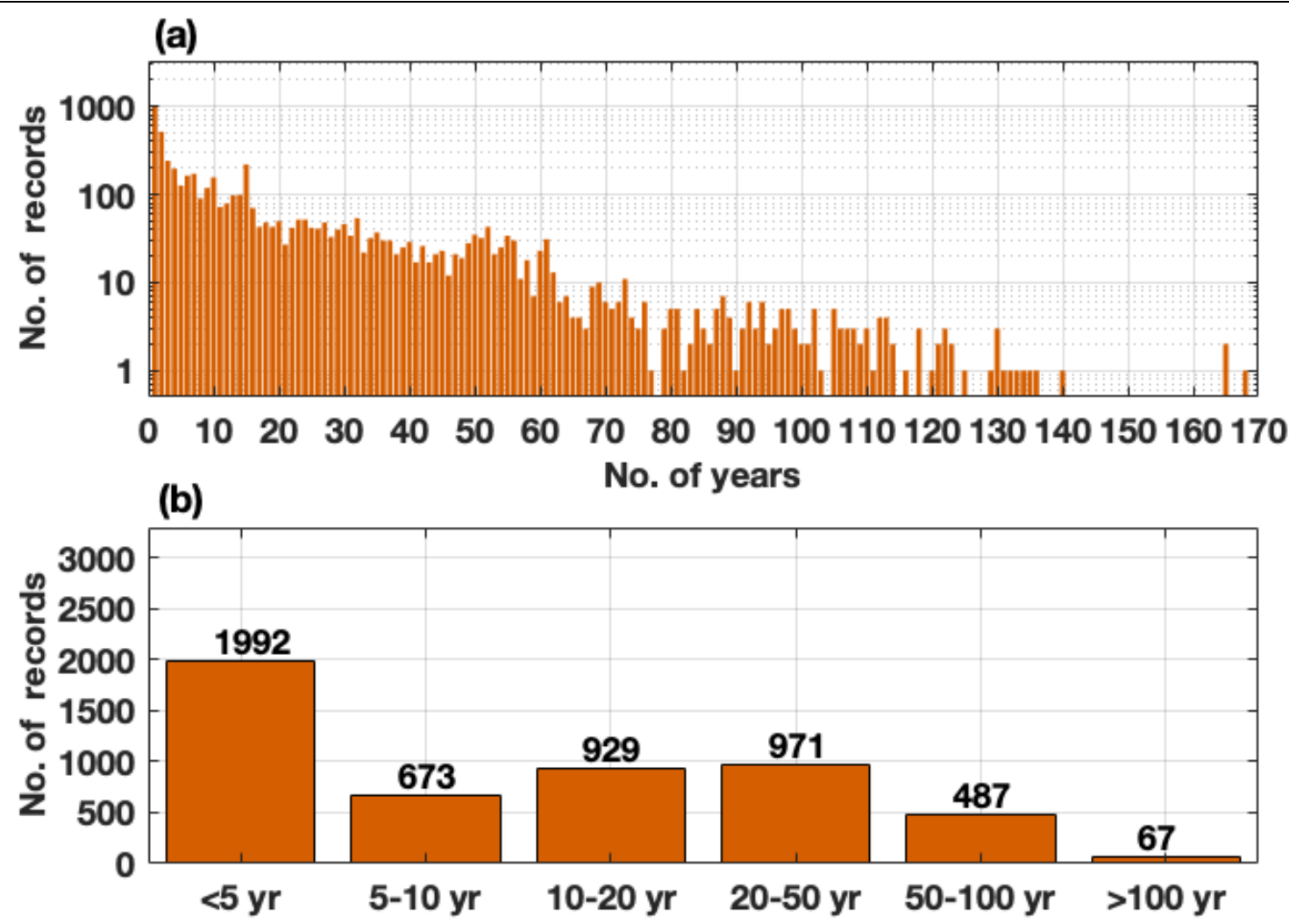

(c) Years

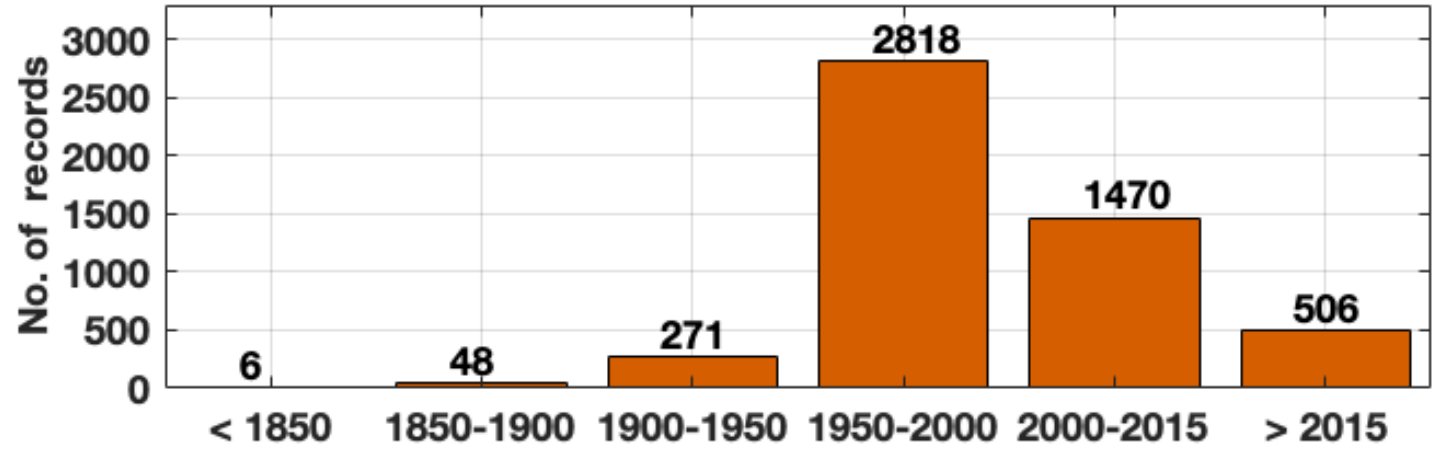

(d)

Start year

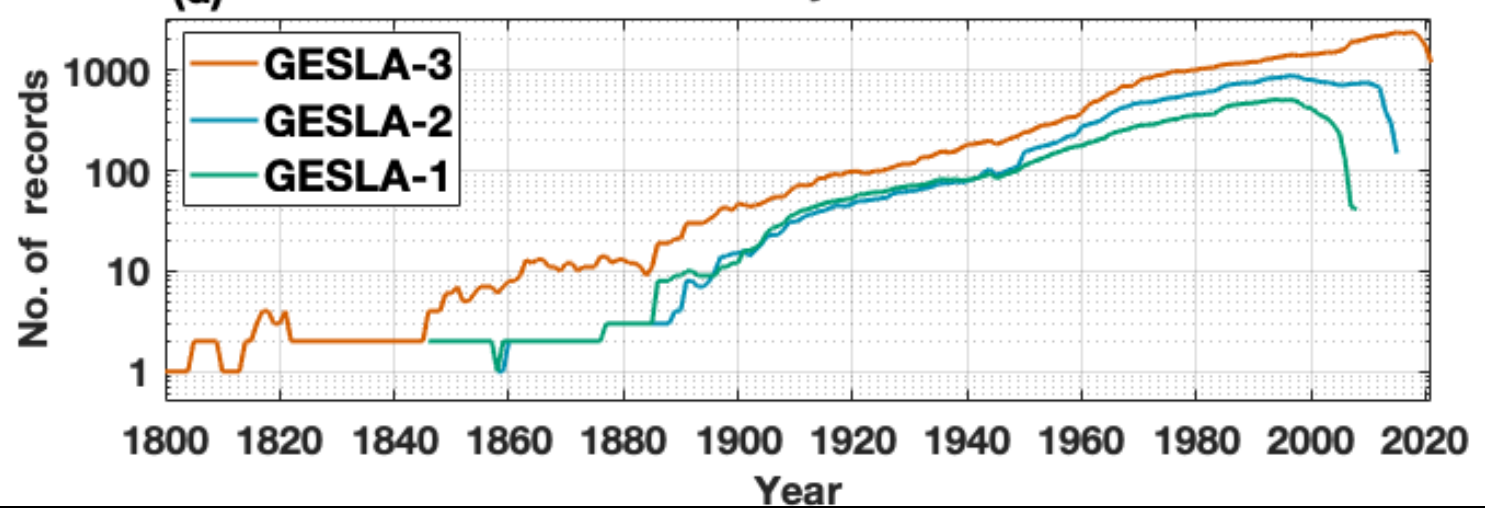

Figure 4: (a) Number of records with the stated number of years of data in GESLA-3 (note the logarithmic scale); (b) number of records with a particular number of years; (c) number of records with data starting in a particular span of years; and (d) number of records with data in a particular year in GESLA-3, -2 and -1 (note the logarithmic scale). 


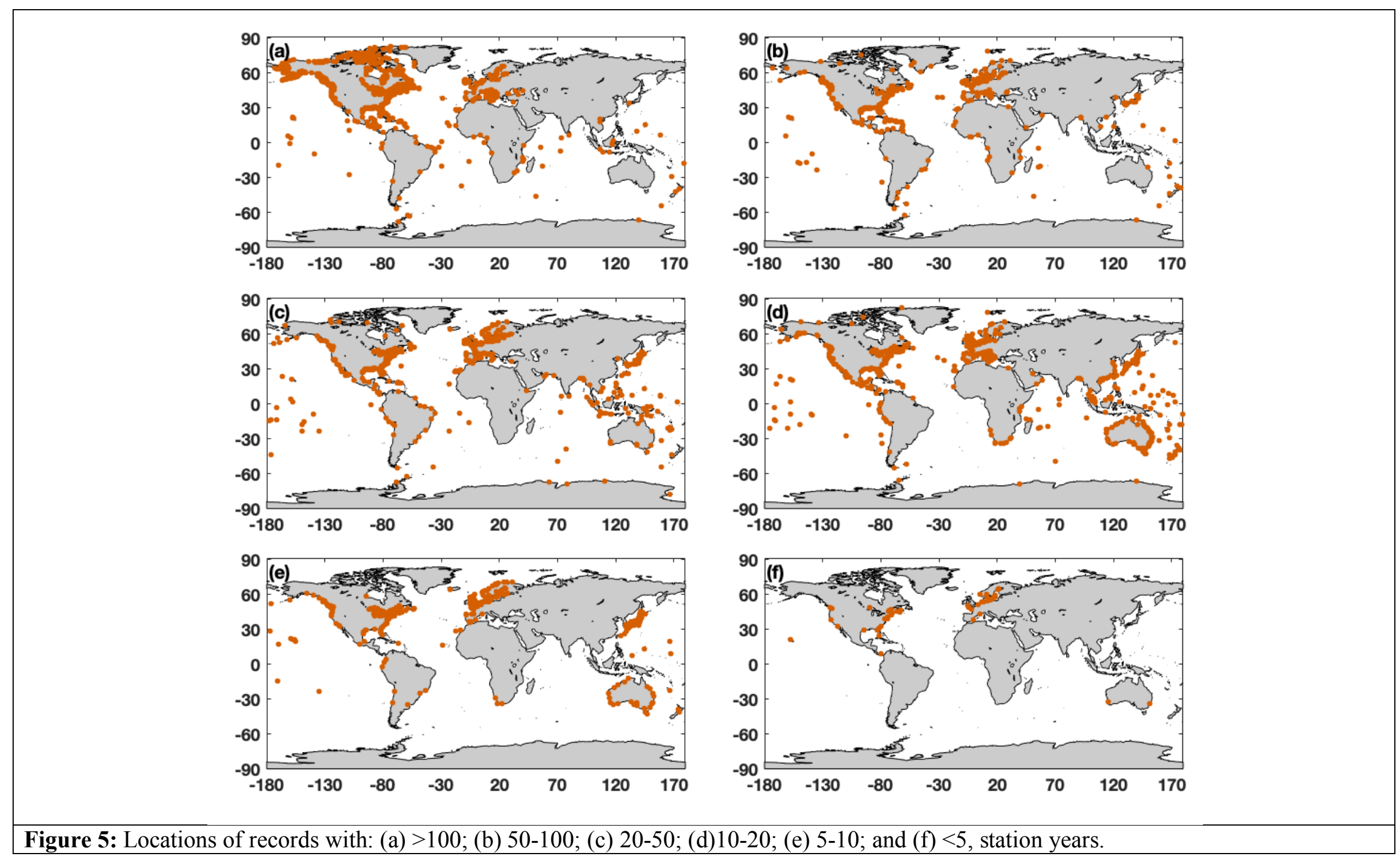




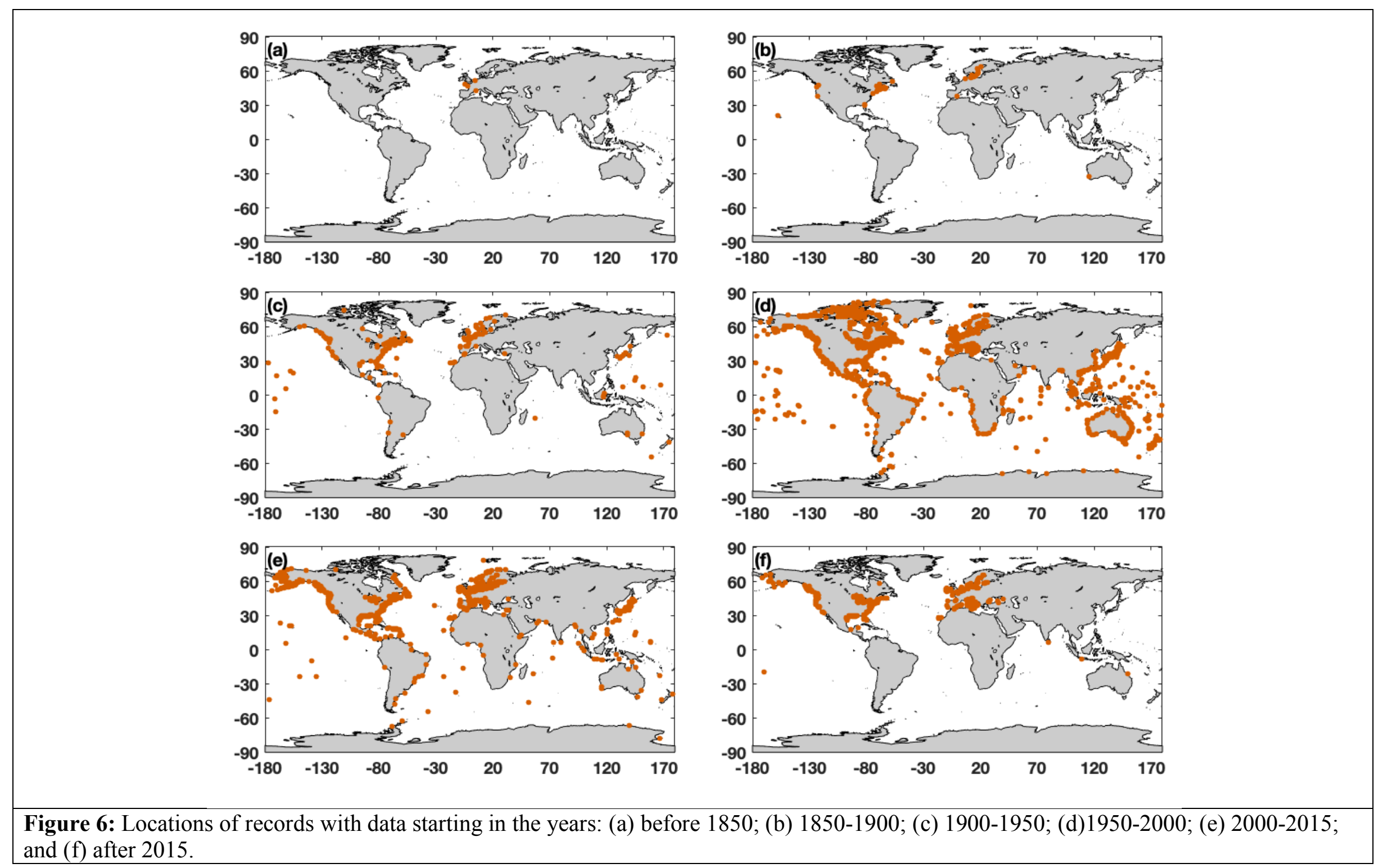

